\title{
Secondary organic aerosol formation from the photooxidation of isoprene, 1,3-butadiene, and 2,3-dimethyl-1,3-butadiene under high $\mathrm{NO}_{\mathrm{x}}$ conditions
}

\author{
K. Sato ${ }^{1,2, *}$, S. Nakao ${ }^{1,3}$, C. H. Clark ${ }^{1,3}$, L. Qi ${ }^{1,3}$, and D. R. Cocker III ${ }^{1,3}$ \\ ${ }^{1}$ Bourns College of Engineering - Center for Environmental Research \& Technology, University of California, Riverside, \\ 1084 Columbia Ave., Riverside, CA 92507, USA \\ ${ }^{2}$ Asian Environment Research Group, National Institute for Environmental Studies, 16-2 Onogawa, Tsukuba, \\ Ibaraki, 305-8506, Japan \\ ${ }^{3}$ Department of Chemical and Environmental Engineering, University of California, Riverside, CA 92521, USA \\ *now at: Center for Regional Environmental Research, National Institute for Environmental Studies, 16-2 Onogawa, \\ Tsukuba, Ibaraki, 305-8506, Japan
}

Received: 25 January 2011 - Published in Atmos. Chem. Phys. Discuss.: 7 February 2011

Revised: 30 June 2011 - Accepted: 21 July 2011 - Published: 25 July 2011

\begin{abstract}
Secondary organic aerosol (SOA) formation from atmospheric oxidation of isoprene has been the subject of multiple studies in recent years; however, reactions of other conjugated dienes emitted from anthropogenic sources remain poorly understood. SOA formation from the photooxidation of isoprene, isoprene- $1-{ }^{13} \mathrm{C}, 1,3-$ butadiene, and 2,3-dimethyl-1,3-butadiene is investigated for high $\mathrm{NO}_{\mathrm{x}}$ conditions. The SOA yield measured in the 1,3butadiene $/ \mathrm{NO}_{\mathrm{x}} / \mathrm{H}_{2} \mathrm{O}_{2}$ irradiation system $(0.089-0.178)$ was close to or slightly higher than that measured with isoprene under similar $\mathrm{NO}_{\mathrm{x}}$ conditions (0.077-0.103), suggesting that the photooxidation of 1,3-butadiene is a possible source of SOA in urban air. In contrast, a very small amount of SOA particles was produced in experiments with 2,3-dimethyl1,3-butadiene. Off-line liquid chromatography - mass spectrometry analysis revealed that the signals of oligoesters comprise a major fraction $(0.10-0.33)$ of the signals of the SOA products observed from all dienes investigated. The oligoesters originate from the unsaturated aldehyde gas phase diene reaction products; namely, semi-volatile compounds produced by the oxidation of the unsaturated aldehyde undergo particle-phase oligoester formation. Oligoesters produced by the dehydration reaction between nitrooxypolyol and 2-methylglyceric acid monomer or its oligomer were also characterized in these experiments with isoprene as the
\end{abstract}

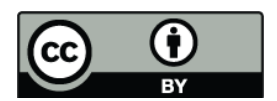

Correspondence to: D. R. Cocker III (dcocker@engr.ucr.edu) starting diene. These oligomers are possible sources of the 2methyltetrols found in ambient aerosol samples collected under high $\mathrm{NO}_{\mathrm{x}}$ conditions. Furthermore, in low-temperature experiments also conducted in this study, the SOA yield measured with isoprene at $278 \mathrm{~K}$ was $2-3$ times as high as that measured at $300 \mathrm{~K}$ under similar concentration conditions. Although oligomerization plays an important role in SOA formation from isoprene photooxidation, the observed temperature dependence of SOA yield is largely explained by gas/particle partitioning of semi-volatile compounds.

\section{Introduction}

Isoprene is the most abundant nonmethane hydrocarbon emitted into the atmosphere, mainly originating from biogenic sources (Guenther et al., 2006). SOA formation during isoprene oxidation has been investigated via laboratory studies by many researchers (e.g. Pandis et al., 1991; Miyoshi et al., 1994; Jang et al., 2002; Edney et al., 2005; Kroll et al., 2005, 2006; Böge et al., 2006; Dommen et al., 2006; Surratt et al., 2006; Szmigielski et al., 2007; Sato, 2008; Kleindienst et al., 2009). The products formed from isoprene photooxidation (i.e. 2-methyltetrols, $\mathrm{C}_{5}$-alkenetriols, and 2methylglyceric acid) have been observed in ambient fine particles (Claeys et al., 2004a,b, 2010; Wang et al., 2005; Xia and Hopke, 2006; Clements and Seinfeld, 2007; Fu et al., $2009,2010 \mathrm{a}, \mathrm{b})$. The atmospheric oxidation of isoprene is

Published by Copernicus Publications on behalf of the European Geosciences Union. 
currently estimated to be the single largest source of SOA in the atmosphere (Henze and Seinfeld, 2006; Henze et al., 2008; Hallquist et al., 2009; Carlton et al., 2009).

Isoprene and other conjugated dienes are also emitted in urban environments from petrol and diesel engine exhaust or fuel vapor (Jemma et al., 1995; Shi and Harrison, 1997; Smith et al., 2002; Nelson et al., 2008; Agrawal et al., 2008), and measurements in the urban environment have been reported (Jeffries, 1995; Calvert et al., 2002; Liu et al., 2008). A representative conjugated diene emitted from anthropogenic sources is 1,3-butadiene, which is more volatile than isoprene. However, SOA can be produced from 1,3-butadiene if its oxidation products were to undergo particle-phase oligomerization. Three previous studies have investigated SOA formation from the photooxidation of 1,3butadiene (Kroll et al., 2005; Angove et al., 2006; Sato, 2008), but the yield and the composition of SOA formed from this reaction remain poorly understood. In this study, we experimentally investigate the formation of SOA from the photooxidation of conjugated dienes in the presence of $\mathrm{NO}_{\mathrm{x}}$ to improve our understanding of SOA formation from these reactions in urban air.

The major particle-phase products formed in the presence of $\mathrm{NO}_{\mathrm{x}}$ from isoprene photooxidation are oligoesters; these oligoesters are produced by the aerosol-phase oligomerization of 2-methylglyceric acid (Surratt et al., 2006, 2010; Szmigielski et al., 2007; Chan et al., 2010). 2-Methyltetrols and $\mathrm{C}_{5}$-alkenetriols are formed as particle-phase products under low $\mathrm{NO}_{\mathrm{x}}$ conditions (Surratt et al., 2006; Kleindienst et al., 2009; Paulot et al., 2009; Surratt et al., 2010) but are not produced under high $\mathrm{NO}_{\mathrm{x}}$ conditions (Surratt et al., 2006). However, 2-methyltetrols are also found in ambient particles even under high $\mathrm{NO}_{\mathrm{x}}$ conditions (Edney et al., 2005; Claeys et al., 2010). A possible source of 2-methyltetrols in the presence of $\mathrm{NO}_{\mathrm{x}}$ is the decomposition of nitrooxypolyols (Sato, 2008; Szmigielski et al., 2010); however, experimental evidence of nitrooxypolyol formation during isoprene photooxidation under high $\mathrm{NO}_{\mathrm{x}}$ conditions is still limited. Another likely source of 2-methyltetrols is the decomposition of organosulfates containing a nitrooxypolyol residue. These compounds are formed from isoprene in the presence of $\mathrm{NO}_{\mathrm{x}}$ and sulfuric acid, and have been detected in ambient fine aerosol (Surratt et al., 2007, 2008; Gómez-González et al., 2008).

During oligoester formation from isoprene photooxidation, particle-phase oligomerization occurs following the gas-to-particle absorption of semi-volatile products. The gasto-particle equilibrium shifts to the particle side with decreasing temperature (Odum et al., 1996; Takekawa et al., 2003). On the other hand, the rate of particle-phase oligomerization decreases with decreasing temperature if the oligomerization process has a substantial activation barrier. Measurement of the temperature dependence of SOA yield from the reaction of isoprene will provide a better understanding of SOA formation involving oligomerization in the particle phase. To

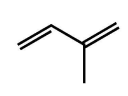

Isoprene (ISO)

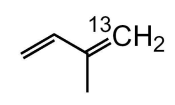

Isoprene-1-13C (ISO-13C)

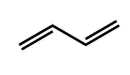

1,3-Butadiene (BD)

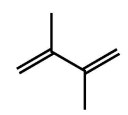

2,3-Dimethyl(DMB) 1,3-butadiene

Fig. 1. Conjugated dienes used in this study.

our knowledge, the temperature dependence of aerosol yield or aerosol composition during isoprene photooxidation has never been investigated.

In this study, SOA formation from the photooxidation of isoprene (ISO), isoprene-1-1 ${ }^{13} \mathrm{C}$ (ISO-13C), 1,3-butadiene (BD), and 2,3-dimethyl-1,3-butadiene (DMB) was investigated under high $\mathrm{NO}_{\mathrm{x}}$ conditions (Fig. 1). The aims of this study were to verify the known mechanism of SOA formation from isoprene/ $\mathrm{NO}_{\mathrm{x}}$ photooxidation and to elucidate the mechanism of SOA formation from the reactions of other conjugated dienes. We explored particle-phase products paying attention not only to known oligoester products but also to nitrooxypolyols and their derivatives. Furthermore, we studied the temperature dependence of SOA yield and SOA composition during isoprene photooxidation.

\section{Experimental section}

\subsection{Materials}

Isoprene (Aldrich, 99\%), isoprene-1- ${ }^{13} \mathrm{C}$ (Aldrich, 99 atom $\%{ }^{13} \mathrm{C}, 97 \%-\mathrm{CP}$ ), 1,3-butadiene (Aldrich, $99 \%$ ), and 2,3-dimethyl-1,3-butadiene (Aldrich, $98 \%$ ) were used as reactants. Hydrogen peroxide (Aldrich, $50 \%$ in $\mathrm{H}_{2} \mathrm{O}$ ) was used as an $\mathrm{OH}$ radical source without further concentration.

\subsection{Experimental procedure}

Table 1 shows the experimental conditions of this study. All experiments were conducted using the UCR CE-CERT 90$\mathrm{m}^{3}$ environmental chamber (Carter et al., 2005; Malloy et al., 2009; Qi et al., 2010). Two Teflon $90-\mathrm{m}^{3}$ reactors located in a $450-\mathrm{m}^{3}$ enclosure were ventilated by dry purified air (dew point less than $233 \mathrm{~K}$ ). Prior to an experiment, the reactors were filled with dry purified air. Nitrogen oxide (22-940 ppb), conjugated diene (20-965 ppb), and hydrogen peroxide $(0-3 \mathrm{ppm})$ were injected into each reactor using nitrogen carrier gas. The gas mixture in each reactor was then stirred using a mixing fan for $1 \mathrm{~min}$. Complete mixing was ensured by monitoring $\mathrm{NO}_{\mathrm{x}}$ and diene concentration using a chemiluminescence $\mathrm{NO} / \mathrm{NO}_{\mathrm{x}}$ analyzer (Teco, Model 42C) and gas chromatography with flame ionization detection (GC-FID; Agilent, Model 6890N). The two reactors were then irradiated by black lights (Sylvania, 350BL, 
Table 1. Experimental conditions and results.

\begin{tabular}{|c|c|c|c|c|c|c|c|}
\hline $\operatorname{Run}^{\mathrm{a}}$ & Compound & $\begin{array}{r}{[\text { Diene }]_{0}} \\
(\mathrm{ppb})\end{array}$ & $\begin{array}{r}{\left[\mathrm{NO}_{\mathrm{x}}\right]_{0}^{\mathrm{b}}} \\
(\mathrm{ppb})\end{array}$ & $\begin{array}{r}\text { Diene reacted } \\
\left(\mu \mathrm{g} \mathrm{m}^{-3}\right)\end{array}$ & $\begin{array}{r}\mathrm{SOA}^{\mathrm{c}} \\
\left(\mu \mathrm{g} \mathrm{m}^{-3}\right)\end{array}$ & $\begin{array}{l}\text { SOA } \\
\text { Yield }\end{array}$ & Note \\
\hline EPA1058W & ISO & 573 & 940 & 1595 & 24 & 0.015 & $\mathrm{~d}$ \\
\hline EPA1070E & ISO & 965 & 56 & 1734 & 32 & 0.018 & $\mathrm{~d}$ \\
\hline EPA1069W & ISO & 552 & 43 & 1350 & 25 & 0.019 & $\mathrm{~d}$ \\
\hline EPA1069E & ISO & 247 & 42 & 688 & 16 & 0.023 & $\mathrm{~d}$ \\
\hline EPA1058E & ISO & 255 & 398 & 710 & 26 & 0.037 & $\mathrm{~d}$ \\
\hline EPA1068W & ISO & 115 & 44 & 320 & 12 & 0.038 & $\mathrm{~d}$ \\
\hline EPA1082E & ISO & 376 & 273 & 1046 & 46 & 0.044 & $\mathrm{~d}$ \\
\hline EPA1078W & ISO & 115 & 257 & 320 & 15 & 0.047 & $\mathrm{~d}$ \\
\hline EPA1070W & ISO & 957 & 907 & 2663 & 136 & 0.051 & $\mathrm{~d}$ \\
\hline EPA1068E & ISO & 49 & 42 & 136 & 7 & 0.052 & $\mathrm{~d}$ \\
\hline EPA1078E & ISO & 115 & 257 & 320 & 17 & 0.053 & $\mathrm{~d}$ \\
\hline EPA1087E & ISO & 244 & 250 & 678 & 36 & 0.053 & $\mathrm{~d}$ \\
\hline EPA1061E & ISO & 20 & 22 & 55 & 3 & 0.055 & $\mathrm{~d}$ \\
\hline EPA1060W & ISO & 145 & 240 & 403 & 28 & 0.069 & $\mathrm{~d}$ \\
\hline EPA1061W & ISO & 42 & 50 & 116 & 9 & 0.077 & $\mathrm{~d}$ \\
\hline EPA1060E & ISO & 66 & 103 & 184 & 19 & 0.103 & $\mathrm{~d}$ \\
\hline EPA1115E & ISO & 37 & 268 & 103 & 8 & 0.077 & $\mathrm{e}$ \\
\hline EPA1108W & ISO & 240 & 256 & 668 & 63 & 0.094 & $\mathrm{e}$ \\
\hline EPA1108E & ISO & 115 & 256 & 320 & 33 & 0.103 & $\mathrm{e}$ \\
\hline EPA1087W & ISO & 338 & 315 & 939 & 6 & 0.006 & $\mathrm{~d}, \mathrm{f}$ \\
\hline EPA1090E & ISO & 197 & 339 & 548 & 6 & 0.011 & $\mathrm{~d}, \mathrm{~g}$ \\
\hline EPA1090W & ISO & 199 & 343 & 555 & 9 & 0.016 & $\mathrm{~d}, \mathrm{~g}$ \\
\hline EPA1148E & ISO & 133 & 300 & 371 & 39 & 0.105 & $\mathrm{~d}, \mathrm{~h}$ \\
\hline EPA1148W & ISO & 132 & 297 & 368 & 56 & 0.152 & $\mathrm{~d}, \mathrm{~h}$ \\
\hline EPA1082W & ISO-13C & 317 & 275 & 881 & 50 & 0.057 & $\mathrm{~d}$ \\
\hline EPA1072W & $\mathrm{BD}$ & 106 & 333 & 234 & 5 & 0.021 & $\mathrm{~d}$ \\
\hline EPA1072E & $\mathrm{BD}$ & 51 & 146 & 112 & 4 & 0.036 & $\mathrm{~d}$ \\
\hline EPA1094E & $\mathrm{BD}$ & 112 & 267 & 247 & 22 & 0.089 & e \\
\hline EPA1094W & $\mathrm{BD}$ & 269 & 267 & 594 & 66 & 0.111 & $\mathrm{e}$ \\
\hline EPA1132E & $\mathrm{BD}$ & 41 & 250 & 91 & 11 & 0.121 & $\mathrm{e}$ \\
\hline EPA1132W & $\mathrm{BD}$ & 214 & 249 & 473 & 84 & 0.178 & $\mathrm{e}$ \\
\hline EPA1137W & $\mathrm{BD}$ & 227 & 275 & 501 & 22 & 0.044 & $e, f$ \\
\hline EPA1137E & $\mathrm{BD}$ & 228 & 276 & 504 & 30 & 0.060 & $e, f$ \\
\hline EPA1104E & DMB & 115 & 259 & 386 & 1 & 0.003 & $\mathrm{e}$ \\
\hline EPA1104W & DMB & 250 & 258 & 839 & 4 & 0.005 & $\mathrm{e}$ \\
\hline EPA1115W & DMB & 291 & 267 & 976 & 7 & 0.007 & $\mathrm{e}$ \\
\hline
\end{tabular}

${ }^{a}$ Typical experiments were conducted in the presence of $\sim 3 \mathrm{ppm} \mathrm{H}_{2} \mathrm{O}_{2}$ at $300 \pm 1 \mathrm{~K}$, unless otherwise specified. ${ }^{\mathrm{b}} \mathrm{NO}_{\mathrm{x}}$ used in all experiments was pure NO. ${ }^{\mathrm{c}}$ SOA mass was converted from SMPS volume assuming $1 \mathrm{~g} \mathrm{~cm}^{-3}$ density. ${ }^{\mathrm{d}} \mathrm{NO}_{2}$ photolysis rate was set to $0.12 \mathrm{~min}^{-1}$. ${ }^{\mathrm{e}} \mathrm{NO}_{2}$ photolysis rate was set to 0.40 min ${ }^{-1}$. ${ }^{\mathrm{f}} \mathrm{No}$ hydroxyl radical source $\left(\mathrm{H}_{2} \mathrm{O}_{2}\right)$ was used. ${ }^{\mathrm{g}}$ Lights-off experiment. ${ }^{\mathrm{h}}$ Low-temperature experiment at $278 \mathrm{~K}$.

the light intensity is peaked at $350 \mathrm{~nm}$ with $40 \mathrm{~nm}$ FWHM). The $\mathrm{NO}_{2}$ photolysis rates were 0.12 and $0.40 \mathrm{~min}^{-1}$ when 80 and 276 black lights were used at $300 \mathrm{~K}$, respectively. The pressure of each reactor was maintained at $5 \mathrm{~Pa}$ higher than the enclosure by pressing the reactor wall in order to avoid any leakage of contaminants; thus, the reactor volume decreased with time. An experiment was finished when the volume of a chamber decreased to one-third the initial value. The experimental duration ranged from 6 to $9 \mathrm{~h}$ during the present experimental period. The $\mathrm{H}_{2} \mathrm{O}_{2}$ photolysis rate when 276 lights were used was evaluated to be $6.4 \times 10^{-4} \mathrm{~min}^{-1}$ from the $\mathrm{NO}_{2}$ photolysis rate, the black light spectrum, and the $\mathrm{NO}_{2}$ and $\mathrm{H}_{2} \mathrm{O}_{2}$ absorption spectra (DeMore et al., 1997). No seed aerosol was used in all experiments.

The air temperature in the enclosure was controlled by an air handler with $\sim 105 \mathrm{~kW}$ cooling power. Most experiments were conducted at room temperature $(300 \pm 1 \mathrm{~K})$ while two experiments with isoprene were conducted at a low temperature $(278 \pm 1 \mathrm{~K})$. In order to correct the change in light intensity caused by temperature decrease, the number of lights used at $278 \mathrm{~K}$ was adjusted to reproduce the $\mathrm{NO}_{2}$ photolysis rate of experiments at $300 \mathrm{~K}$ (Qi et al., 2010). 
Aerosol particles in the reactors were collected on a Teflon membrane disk filter (Pall, Teflo ${ }^{\circledR}, 2 \mu \mathrm{m}$ pore, $47-\mathrm{mm}$ diameter) for off-line analysis of particle-phase products. The samples were collected for $30-120 \mathrm{~min}$ at a flow rate of $251 \mathrm{~min}^{-1}$. Pretreatment of sample filters was conducted within $48 \mathrm{~h}$ of sampling. Sample filters were stored in a freezer until pretreatment. Each sample filter was extracted by sonication in $5 \mathrm{ml}$ of methanol for $30 \mathrm{~min}$. Each extract was concentrated under a gentle stream of dry nitrogen until dried. Each sample was reconstituted with 1-ml acetic $\mathrm{acid} / \mathrm{methanol} / \mathrm{water}$ solution $(\mathrm{v} / \mathrm{v} / \mathrm{v}=0.1 / 49.95 / 49.95)$ and was then used as an analytical sample.

\subsection{Instruments}

The concentrations of gaseous compounds were measured by two GC-FID instruments, an $\mathrm{NO} / \mathrm{NO}_{\mathrm{x}}$ analyzer, and an ultraviolet absorption ozone analyzer (Dasibi, Model 1003-AH). Furthermore, reactant and product volatile organic compounds (VOCs) were measured by a high sensitivity proton transfer reaction - mass spectrometer (PTR-MS; Ionicon).

Particle-size distribution between 28 and $730 \mathrm{~nm}$ was measured using two custom-made scanning mobility particle sizer (SMPS) instruments similar in design to those described elsewhere (Cocker III et al., 2001). Particle number and volume were wall-loss corrected using the method of Bowman et al. (1997). Particle-mass loading was calculated assuming a unit density. Note that the present yield would be higher if a higher aerosol density is used. The volatility of particles at $373 \mathrm{~K}$ was measured by a custommade volatility tandem differential mobility analyzer (VTDMA) having a similar design as that described elsewhere (Qi et al., 2010). The volume fraction remaining (VFR) was monitored for 75,100 , and $125 \mathrm{~nm}$ particles, and the VFR was confirmed to be independent of the particle diameter within an experimental uncertainty. The residence time of the aerosol in the thermodenuder was $17 \mathrm{~s}$, which is sufficiently long under present experimental conditions (An et al., 2007). The off-line analysis of SOA particles was conducted by high-pressure liquid chromatography/accurate mass ( $3 \mathrm{ppm}$ ) time-of-flight mass spectrometry (LC-TOFMS; Agilent, Model 6210). A 10- $\mu$ l aliquot of analytical sample was injected into the LC-TOFMS instrument. The mobile phases used were $0.1 \%$ acetic acid aqueous solution (A) and $0.1 \%$ acetic acid methanolic solution (B). The total flow rate of mobile phases was set to $0.5 \mathrm{ml} \mathrm{min}-1$. The concentration of mobile phase B was set to $50 \%$ in the flow-injection analysis conducted without a column. On the other hand, in the column-injection analysis, the concentration of mobile phase B was set to $5 \%$ as an initial value and was linearly increased to $90 \%$ in $30 \mathrm{~min}$. The column used was an octadecyl silica gel column (Agilent, $4.6 \times 150 \mathrm{~mm}$ Eclipse, XDB-C18); the temperature of the column was set to $298 \mathrm{~K}$. Analytes were ionized by electrospray ionization (ESI) method in negative polarity mode; the temperature of the vaporizer was set to $448 \mathrm{~K}$; nebulizer gas pressure was set to $276 \mathrm{kPa}$; and fragmentor voltage was set to $160 \mathrm{~V}$. The ions formed were analyzed by a time-of-flight mass spectrometer.

The real-time mass spectrum of SOA was measured by a time-of-flight aerosol mass spectrometer (ToF-AMS; Aerodyne); details of the instrument are explained elsewhere (Drewnick et al., 2005). Particles collected through an aerodynamic lens were vaporized by a heater at $873 \mathrm{~K}$. Vaporized compounds were ionized by electron ionization (EI) and analyzed by the time-of-flight mass spectrometer in $\mathrm{V}$ mode, which was selected to detect oligomers in a high sensitivity. The mass resolution in V mode was typically $\sim 2700$, and this enabled us to resolve the peaks of $\mathrm{NO}^{+}(\mathrm{m} / z$ 29.997) and $\mathrm{CH}_{2} \mathrm{O}^{+}(\mathrm{m} / \mathrm{z}, 30.010)$. Data obtained was numerically analyzed by the ToF-AMS Analysis Toolkit program version 1.48 and ToF-AMS HR Analysis program version 1.07 (ToF-AMS Software Downloads, 2009).

\section{SOA formation}

\subsection{Time profile}

Figure 2a shows the time profiles of gaseous reactants and products obtained from an isoprene photooxidation experiment (EPA1078W). The concentrations of isoprene and NO decreased with irradiation time. Figure $2 b$ shows a time profile of SOA mass concentration obtained in the same experiment. The plotted SOA concentrations are values obtained after wall-loss correction. The SOA mass concentration increased to above a detectable level after most of the initial NO was consumed. Similar results were observed under lower $\mathrm{NO}_{\mathrm{x}}$ conditions (EPA1069W and EPA1070E; $\left.\mathrm{NO}_{\mathrm{x}} / \mathrm{HC}=0.06-0.08\right)$ as well as in this experiment $\left(\mathrm{NO}_{\mathrm{x}} / \mathrm{HC}=2.23\right)$. The SOA concentration continued to increase after most of the isoprene was consumed. The SOA mass concetration had not leveled off by the end of the experiment. This was typical in experiments in which the $\mathrm{NO}_{2}$ photolysis rate was $0.12 \mathrm{~min}^{-1}$. Reported SOA yields in these experiments are probably underestimated by low extent of reaction.

Figure $2 \mathrm{c}$ shows the time profiles of PTR-MS signals at $\mathrm{m} / \mathrm{z} 69$ and 71. Isoprene, having a molecular weight of 68 , was detected by PTR-MS as protonated molecules at $m / z 69$. In the same figure, scaled GC-FID isoprene data is also plotted. The time profile at $m / z 69$ agreed with that of the relative isoprene concentration measured by GC-FID. Methacrolein and methyl vinyl ketone, produced as first-generation products during isoprene oxidation, were detected as protonated molecules at $m / z 71$. Signal intensity at $m / z 71$ increased and then decreased due to the formation and subsequent reactions of these products. SOA concentration increased with decreasing signal intensity at $m / z 71$, suggesting that SOA particles are second- or higher-generation products of isoprene oxidation. 

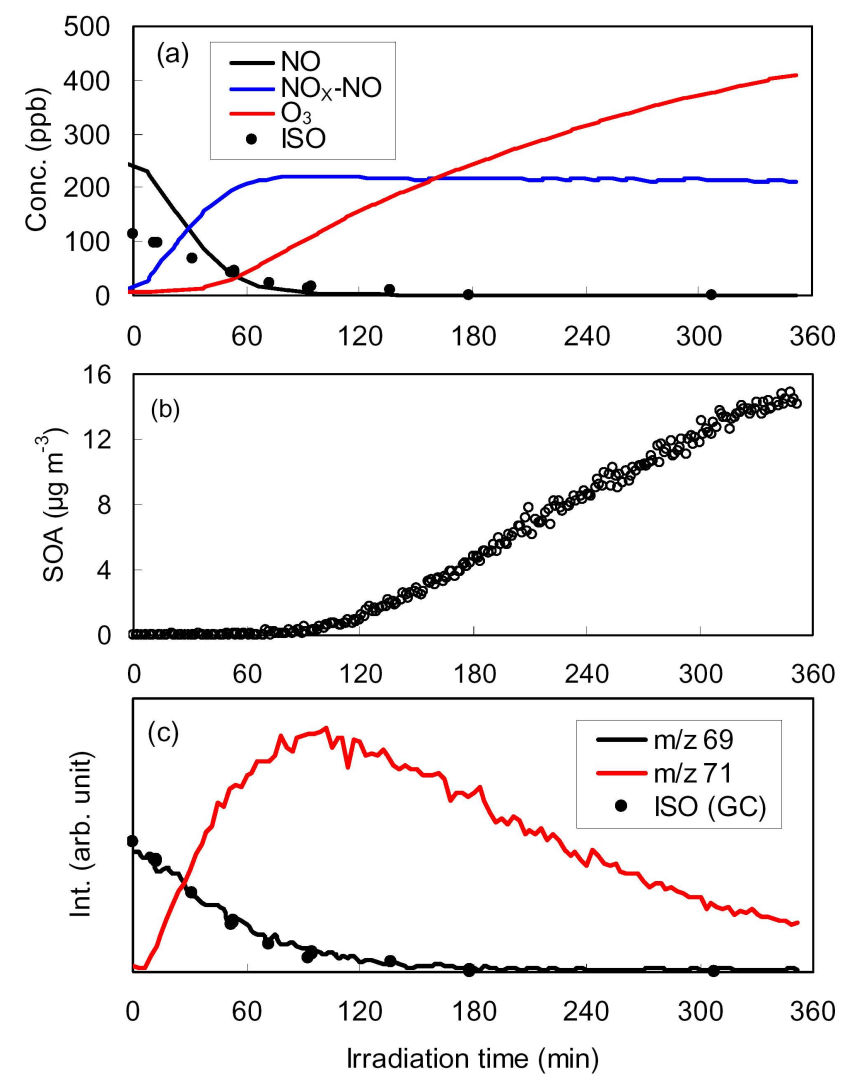

Fig. 2. Time profiles of (a) gas concentration, (b) SOA mass concentration, and (c) PTR-MS signals during isoprene/ $/ \mathrm{NO}_{\mathrm{x}} / \mathrm{H}_{2} \mathrm{O}_{2}$ experiment at $300 \mathrm{~K}(\mathrm{EPA} 1078 \mathrm{~W})$. The $\mathrm{NO}_{2}$ photolysis rate for this run was $0.12 \mathrm{~min}^{-1}$. The $\mathrm{NO}_{\mathrm{x}}$ analyzer used was a chemiluminescence type; $\mathrm{NO}_{\mathrm{x}}$ signals of this instrument include not only the signals of $\mathrm{NO}$ and $\mathrm{NO}_{2}$ but also the signals of $\mathrm{NO}_{\mathrm{y}}$ species (e.g. nitric acid).

\subsection{Time-dependent growth curve}

Time-dependent SOA growth curves (i.e. SOA concentrations plotted as a function of the concentration of hydrocarbon reacted) are used for the analysis of the SOA formation mechanism (Sato et al., 2004; Chan et al., 2007; Kroll and Seinfeld, 2008). Time-dependent growth curves of the reactions with isoprene, 1,3-butadiene, and DMB are shown in Fig. 3. Only experiments with $\mathrm{NO}_{\mathrm{x}}$ ranging from 249-267 ppb were included in Fig. 3 since the yield and the product distribution of SOA during isoprene photooxidation depend strongly on the initial $\mathrm{NO}_{\mathrm{x}}$ concentration (Kroll et al., 2005, 2006; Surratt et al., 2006), Experiment 1078W (Fig. 2) was conducted with a $\mathrm{NO}_{2}$ photolysis rate of only $0.12 \mathrm{~min}^{-1}$; however, the signal at $\mathrm{m} / z 71$, corresponding to methacrolein or methyl vinyl ketone, was still present when the experiment was finished. The $\mathrm{NO}_{2}$ photolysis rate for all experiments in Fig. 3 was therefore raised in subsequent experiments to $0.40 \mathrm{~min}^{-1}$ to ensure complete consumption of $\mathrm{m} / \mathrm{z} 71$ within the limited duration of the experiments.
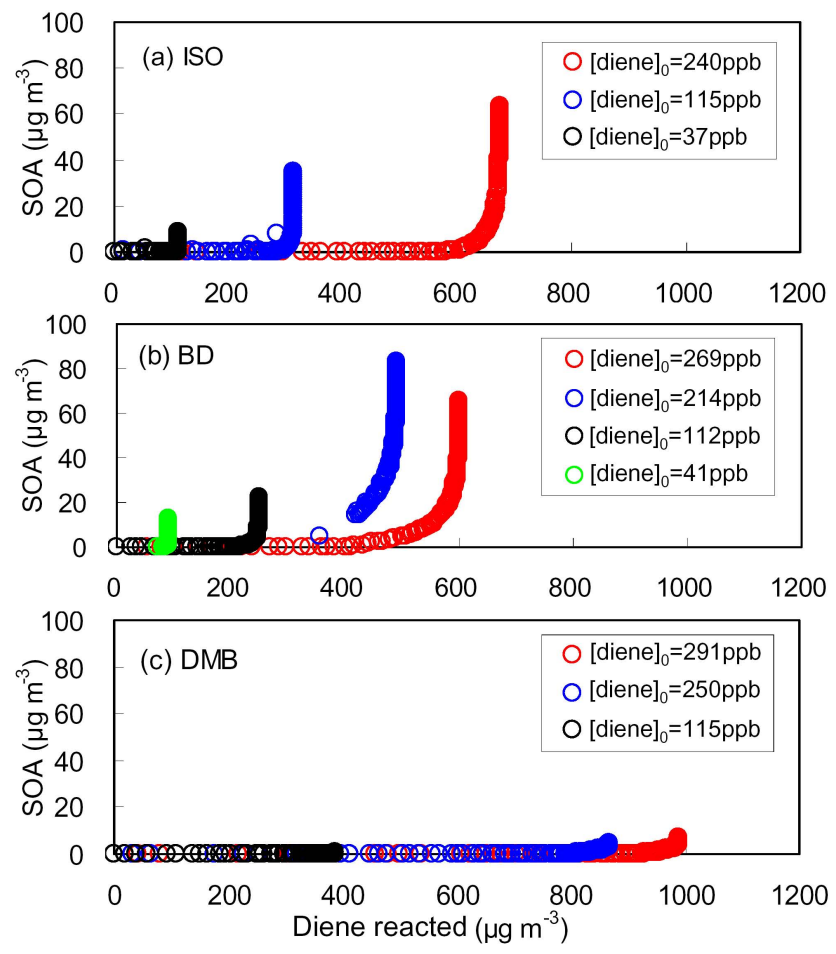

Fig. 3. Time-dependent SOA growth curves measured in diene/ $\mathrm{NO}_{\mathrm{x}} / \mathrm{H}_{2} \mathrm{O}_{2}$ experiments with (a) isoprene (EPA1108W, EPA1108E, EPA1115E), (b) 1,3-butadiene (EPA1094W, EPA1094E, EPA1132W, EPA1132E), and (c) DMB (EPA1104W, EPA1104E, EPA1115W). All results plotted were obtained at initial $\mathrm{NO}_{\mathrm{x}}$ concentrations of 249-267 ppb and at an $\mathrm{NO}_{2}$ photolysis rate of $0.40 \mathrm{~min}^{-1}$.

Figure 3a shows the time-dependent SOA growth curves of the reaction with isoprene. All SOA formation curves were or nearly were vertical because the majority of SOA production occured continued after most of the isoprene was consumed. Similar results were obtained in the range of 37$240 \mathrm{ppb}$ of the initial isoprene concentration. These results confirm that SOA is generated from a second- or highergeneration product. Vertically increasing growth curves are observed when the rate of precursor VOC oxidation is much higher than that following the oxidation of products leading to SOA formation (Kroll and Seinfeld, 2008). This is consistent with the $\mathrm{OH}$ reaction rate of isoprene being 3.2 and 5.5 times as high as that of methacrolein and methyl vinyl ketone, respectively (Atkinson, 1986). SOA yield, calculated using the maximum value of SOA concentration, was $0.077-$ 0.103 .

Similar results were obtained in an experiment with 1,3butadiene (Fig. 3b). The measured SOA yield was 0.0890.178 in the range of $41-269 \mathrm{ppb}$ of diene concentration, close to or slightly higher than the results for isoprene. To our knowledge, this is the first study in which the SOA yield from the reaction of 1,3-butadiene was measured by changing the reactant concentration. Carter et al. (2005) reported a typical 
concentration of background particle matter formation of the present chamber is $0-1 \mu \mathrm{g} \mathrm{m}^{-3}$. Detectable level SOA (4$7 \mu \mathrm{g} \mathrm{m}^{-3}$ ) was produced in the experiments with DMB in the range of $250-291 \mathrm{ppb}$ of diene concentration, but the measured SOA yield (0.005-0.007) was significantly lower than that of isoprene and 1,3-butadiene (Fig. 3c).

\subsection{SOA yield}

Table 1 shows the SOA yield measured in all the present experiments. Typically, SOA concentrations of duplicate experiments agreed within $8 \%$ precision at the same reaction time. EPA1148W and EPA1148E are duplicate experiments. However, the SOA yields measured is these runs (0.152 and $0.105)$ are inconsistent; this is because, the experimental duration of EPA1148E was shorter than EPA1148W due to the difference in chamber leakage.

The SOA yield measured in all the present isoprene/ $\mathrm{NO}_{\mathrm{x}} / \mathrm{H}_{2} \mathrm{O}_{2}$ experiments at $300 \mathrm{~K}$ was $0.015-0.103$. Some of these results were higher than the previous results reported by Kroll et al. (2006) for isoprene/ $/ \mathrm{NO}_{\mathrm{x}} / \mathrm{H}_{2} \mathrm{O}_{2}$ system (0.0140.055). One major difference between the two studies is the aerosol loadings which are known to affect SOA yields (Odum et al., 1996). The aerosol loadings of the present experiments (in which the SOA yield was higher than 0.055) were $8-63 \mu \mathrm{g} \mathrm{m}^{-3}$; these were higher than the previous experiments $\left(1.7-6.7 \mu \mathrm{g} \mathrm{m}^{-3}\right)$. Surratt et al. (2006) examined the isoprene $/ \mathrm{NO}_{\mathrm{x}} / \mathrm{H}_{2} \mathrm{O}_{2}$ system under similar aerosol loading conditions as this study. The SOA yield reported by Surratt et al. (2006) is $0.049-0.080$ and is close to the present result.

Among present yield data of the isoprene/ $\mathrm{NO}_{\mathrm{x}} / \mathrm{H}_{2} \mathrm{O}_{2}$ system, there are data lower than 0.055 in a region $>6.7 \mu \mathrm{g} \mathrm{m}^{-3}$; these cannot be explained by the difference in the aerosol loading. For example, the yield was 0.051 at $136 \mu \mathrm{g} \mathrm{m}^{-3}$ in EPA1070W in which the $\mathrm{NO}_{\mathrm{x}}$ level was very high. The difference in the $\mathrm{NO}_{\mathrm{x}}$ level is known to affect $\mathrm{SOA}$ yields (Carlton et al., 2009). The difference in the $\mathrm{NO}_{\mathrm{x}}$ level as well as the extent of the reaction is a possible reason of these low-yield data.

The SOA yield measured in the absence of $\mathrm{H}_{2} \mathrm{O}_{2}$ was 0.006 (EPA1087W). Literature value of SOA yield in isoprene $/ \mathrm{NO}_{\mathrm{x}}$ system was 0.002-0.049 (Dommen et al., 2006). The SOA yield measured in the absence of $\mathrm{H}_{2} \mathrm{O}_{2}$ was lower than that in the presence of $\mathrm{H}_{2} \mathrm{O}_{2}$. The PTR-MS signal of $m / z 71$ maintained $69 \%$ of its highest level at the end of the experiment in the absence of $\mathrm{H}_{2} \mathrm{O}_{2}$ (EPA1087W), whereas that decreased to $18 \%$ in the presence of $\mathrm{H}_{2} \mathrm{O}_{2}$ (Fig. 2c). The extent of the reaction in the absence of $\mathrm{H}_{2} \mathrm{O}_{2}$ is lower than that in the presence of $\mathrm{H}_{2} \mathrm{O}_{2}$. Further, the $\mathrm{OH}$ concentration and the rate of semi-volatile compound formation increase in the presence of an $\mathrm{OH}$ radical source; these will also affect SOA yields (Carlton et al., 2009). The SOA formation from the heterogeneous reactions with $\mathrm{H}_{2} \mathrm{O}_{2}$ (e.g. Carlton et al., 2006) will be less significant under present dry conditions.

\section{Chemical composition of SOA}

\subsection{LC-TOF mass spectrum}

Flow-injection analysis of SOA off-line samples was conducted by LC-TOFMS (Fig. 4). The results obtained in experiment with isoprene at $300 \mathrm{~K}(\mathrm{EPA} 1108 \mathrm{~W})$ are shown in Fig. 4a. A series of oligomer signals with regular mass difference of 102 amu was found at $m / z, 119,221$, and 323 (series 1A). Similar oligomer signals were found at $\mathrm{m} / \mathrm{z} 266$, 368, 470, 572, 674, 776 (series 2A); $\mathrm{m} / \mathrm{z} 249,351,453,555$, 657, 759 (series 3A); and $m / z 263,365,467,569,671,773$ (series 4A). The mass numbers of these oligomer signals agreed with those measured in previous studies (Surratt et al., 2006; Chan et al., 2010). In this study, a new series of oligomer signals with a regular mass difference of $102 \mathrm{amu}$ was observed at $m / z 327,429,531,633$, and 735 (series 5A). Mass signals of all 1A-5A oligomers were also detected in an experiment without using hydrogen peroxide as an additional OH radical source (EPA1087W). Very low or no signals of $1 \mathrm{~A}-5 \mathrm{~A}$ oligomers were observed in experiments conducted under lower $\mathrm{NO}_{\mathrm{x}}$ conditions (EPA1069W and EPA1070E).

The results of an experiment with isoprene at $278 \mathrm{~K}$ (EPA1148W) are shown in Fig. 4b. Mass signals were found at the same mass numbers as those found in experiments at $300 \mathrm{~K}$. The ratio of the total signals of $5 \mathrm{~A}$ oligomers to the total signals of other $1 \mathrm{~A}-4 \mathrm{~A}$ oligomers measured at $278 \mathrm{~K}$ increased compared with that at $300 \mathrm{~K}$.

Figure $4 \mathrm{c}$ shows the results of an experiment with isoprene-1-13 C (EPA1082W). All mass signals corresponding to $1 \mathrm{~A}-5 \mathrm{~A}$ oligomers found in the experiments with isoprene were observed; however, all mass peaks had shifted due to the substitution by ${ }^{13} \mathrm{C}$ atoms. For example, mass signals corresponding to series $2 \mathrm{~A}$ were detected at $\mathrm{m} / \mathrm{z} 268$, 371, and 474. Mass numbers 268, 371, and 474 were 2, 3, and $4 \mathrm{amu}$ larger than those of the corresponding mass signals measured in the experiments with isoprene; these mass signals were identified as a dimer, a trimer, and a tetramer, respectively. The regular mass difference of all 1A-5A oligomers was $103 \mathrm{amu}$ in the experiment with isoprene-1${ }^{13} \mathrm{C}$.

The results of an experiment with 1,3-butadiene (EPA1094W) are shown in Fig. 4d. A series of oligomer signals with regular mass difference of $88 \mathrm{amu}$ was found at $\mathrm{m} / \mathrm{z} 105,193,281,369,457$, and 545 (series 1B). Another series of oligomer signals with a regular mass difference of $88 \mathrm{amu}$ was also observed at $\mathrm{m} / \mathrm{z} 387,475,563,651$, and 739 (series 5B). In an experiment with DMB (EPA1104W), four series of oligomer signals were observed and identified as series 1A-4A observed in the experiments with isoprene (Fig. 4e).

From data of Fig. 4, the signal ratios of the oligomers identified to the total products observed were determined to be 0.33 (isoprene at $300 \mathrm{~K}$ ), 0.28 (isoprene at $278 \mathrm{~K}), 0.20$ (isoprene- ${ }^{13} \mathrm{C}$ ), 0.10 (1,3-butadiene), and 0.14 

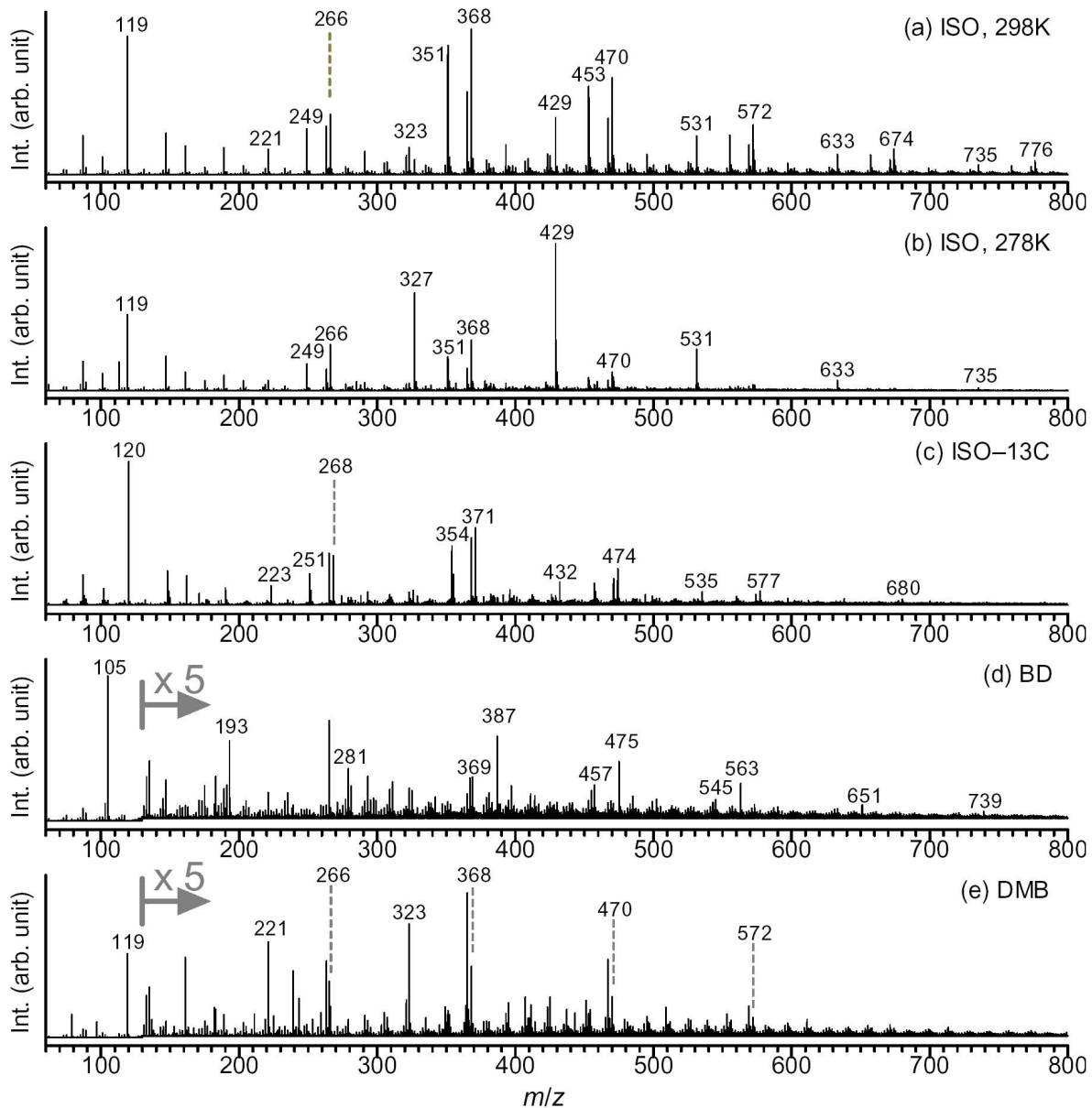

Fig. 4. Flow-injection LC-TOF mass spectra of off-line SOA samples obtained during the photooxidation of (a) isoprene at $300 \mathrm{~K}$ (EPA1108W), (b) isoprene at $278 \mathrm{~K}(\mathrm{EPA} 1148 \mathrm{~W})$, (c) isoprene-1- ${ }^{13} \mathrm{C}(\mathrm{EPA} 1082 \mathrm{~W})$, (d) 1,3-butadiene (EPA1094W), and (e) DMB (EPA1104W).

(2,3-dimethyl-1,3-butadiene). The signals of the oligomers identified comprise a major fraction of the signals of the SOA products observed from all dienes investigated.

\subsection{LC-TOFMS base peak chromatogram}

To confirm the presence of oligomers in the off-line sample solution, column injection analysis was conducted (Fig. 5). The base peak chromatogram measured in the experiment with isoprene (EPA1058E) is shown in Fig. 5a. Mass numbers illustrated with black, red, green, blue, and orange ink correspond to oligomer series $1 \mathrm{~A}, 2 \mathrm{~A}, 3 \mathrm{~A}, 4 \mathrm{~A}$, and 5A, respectively. Chromatographic peaks of each oligomer series with different mass numbers were successfully separated in the column-injection analysis; signals with different mass numbers were obtained from molecules with different degrees of oligomerization. These results confirm that the observed mass signals with high mass numbers were not produced during the ionization process, and oligomers were originally present in the off-line sample solution. The sample solution obtained in EPA1058E and its $1 / 5,1 / 25$, and 1/125 diluted samples were analyzed to measure chromatographic peak areas as a function of relative concentration. Linear relationships were observed between chromatographic peak area and relative concentration for all observed oligomers $(r>0.998, p<0.002)$.

Figure $5 \mathrm{~b}$ shows the results of the experiment with isoprene at $278 \mathrm{~K}(\mathrm{EPA} 1148 \mathrm{~W})$. The ratio of the total peak area of $5 \mathrm{~A}$ oligomers to the total peak area of other $1 \mathrm{~A}-4 \mathrm{~A}$ oligomers measured at $278 \mathrm{~K}$ increased compared with that at $300 \mathrm{~K}$. The results of the experiment with 1,3-butadiene (EPA1132W) are shown in Fig. 5c. Chromatographic peaks of $1 \mathrm{~B}$ and $5 \mathrm{~B}$ oligomers measured in experiments with 1,3butadiene were also successfully separated.

\subsection{Identification of products}

Accurate masses were measured for ions resulting from column-separated oligomers. Measured accurate mass, suggested ion formula, and identified product molecular 

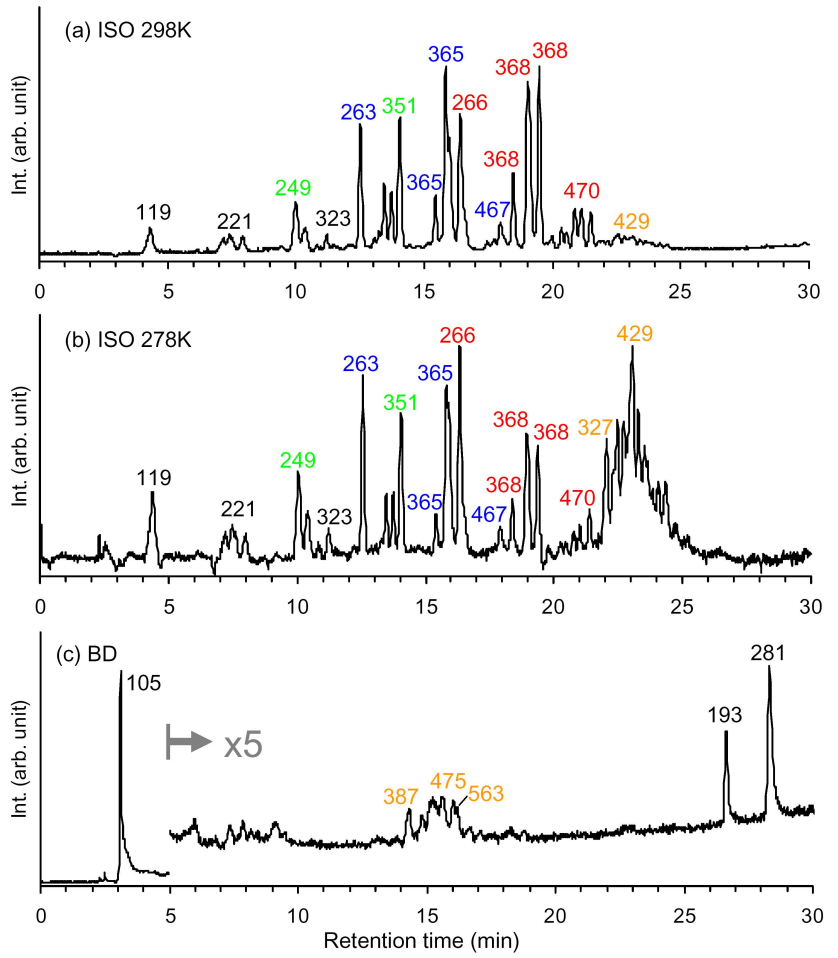

Fig. 5. Typical LC-TOFMS base peak chromatograms of SOA formed from the photooxidation of (a) isoprene at $300 \mathrm{~K}$ (EPA1058E), (b) isoprene at $278 \mathrm{~K}$ (EPA1148W), and (c) 1,3-butadiene (EPA1132W).

structure are shown in Table 2. Generally, analyte molecules are deprotonated to form $[\mathrm{M}-\mathrm{H}]^{-}$ions during the negativemode ESI process. For product identification, all detected ions in this study were assumed to be deprotonated molecules. All ion formulae suggested for oligomer series $1 \mathrm{~A}-4 \mathrm{~A}$ in the present study agreed with those suggested in a recent study by Chan et al. (2010). The products of series $1 \mathrm{~A}, 2 \mathrm{~A}, 3 \mathrm{~A}$, and $4 \mathrm{~A}$ were identified as 2-methylglyceric acid oligoesters and their mononitrates, monoformates, and monoacetates, respectively. The products of series $5 \mathrm{~A}$ were identified as oligomers produced by the dehydration reaction between nitrooxypolyol and 2-methylglyceric acid monomer or its oligomer. It is believed that the 2-methyltetrols found in ambient fine particles under high $\mathrm{NO}_{\mathrm{x}}$ conditions are produced by the decomposition of nitrooxypolyols or organosulfates containing nitrooxypolyol residues (Claeys et al., 2010). Nitrooxypolyols are directly produced by the gas phase isoprene oxidation and/or the particle phase hydrolysis of 5A oligomers under ambient humid conditions. Organosulfates are more commonly detected in ambient particles than are nitrooxypolyols; this is probably because tertiary organonitrates undergo rapid substitution reactions in which nitrate is substituted by water or sulfate (Darer et al., 2011).
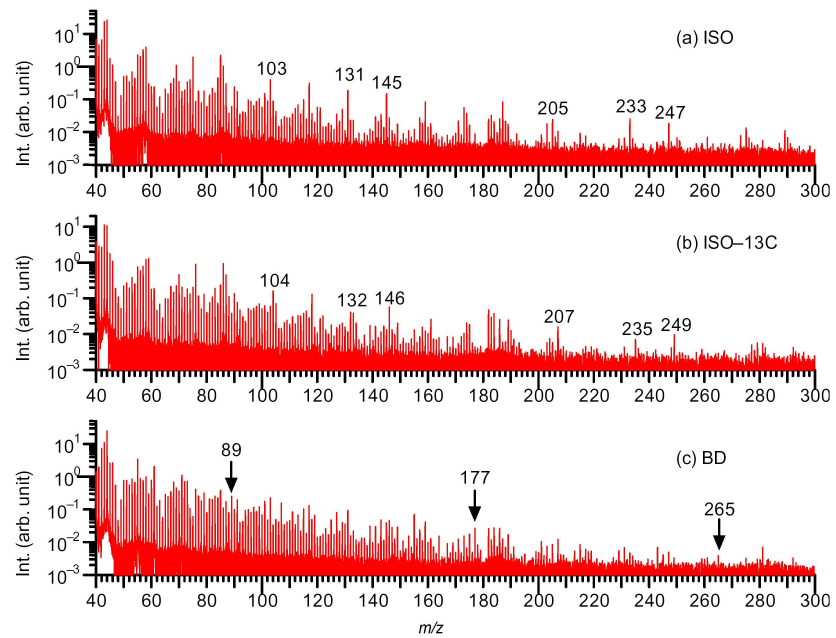

Fig. 6. Typical TOF-AMS raw mass spectra of SOA formed from the photooxidation of (a) isoprene (EPA1170W), (b) isoprene-1${ }^{13} \mathrm{C}$ (EPA1082W), and (c) 1,3-butadiene (EPA1094W).

The products of series 1B formed from 1,3-butadiene oxidation were tentatively identified as glyceric acid monomer and its oligomers. Products of series 5B were tentatively identified as oligoesters produced by the dehydration reaction between nitrooxypolyol and glyceric acid monomer or its oligomer.

\subsection{AMS mass spectrum}

To determine if oligomers are present in suspended SOA particles, particles were directly measured by ToF-AMS. Raw mass spectra, obtained by averaging the data collected for 3$\mathrm{h}$ measurements, are shown in Fig. 6. The results obtained in the experiment with isoprene (EPA1170W) are shown in Fig. 6a. Strong mass signals were observed at $m / 2103$, $131,145,205,233$, and 247. The mass difference between $\mathrm{m} / \mathrm{z}, 103$ and 205, between $\mathrm{m} / \mathrm{z}, 131$ and 233, and between $\mathrm{m} / \mathrm{z}, 145$ and 247 was $102 \mathrm{amu}$. Chan et al. (2010) reported that positive fragment ions formed from the dehydroxylation of $1 \mathrm{~A}, 3 \mathrm{~A}$, and $4 \mathrm{~A}$ oligomers $\left([\mathrm{M}-\mathrm{OH}]^{+}\right)$were observed by ToF-AMS. Mass signals at $m / z$ 103, 131, and 145 were identified as dehydroxylated ions of $1 \mathrm{~A}, 3 \mathrm{~A}$, and $4 \mathrm{~A}$ monomers, whereas mass signals at $m / z 205,233$, and 247 were identified as dehydroxylated ions of $1 \mathrm{~A}, 3 \mathrm{~A}$, and $4 \mathrm{~A}$ dimers (Table 2). The results of the experiment with isoprene- $1-{ }^{13} \mathrm{C}$ (EPA1082W) are shown in Fig. 6b. In the experiment with the isotopomer, the mass numbers of the monomer and dimer peaks shifted by 1 and 2 amu, respectively. These ToF-AMS results confirm that oligomers detected by LC-TOFMS offline analysis are present in SOA particles.

If dehydroxylated fragment ions of $1 \mathrm{~B}$ oligomers formed from 1,3-butadiene oxidation can be detected by ToF-AMS, mass signals with a regular mass difference of 88 amu would be expected to appear at $m / z 89,177$, and 265 (Table 2). The 
Table 2. Oligoesters detected by LC-TOFMS and AMS.

\begin{tabular}{|c|c|c|c|c|c|c|c|c|}
\hline & $n$ & $\begin{array}{l}\text { LC- } \\
\text { TOFMS } \\
\text { measured } \\
{[\mathrm{M}-\mathrm{H}]^{-}}\end{array}$ & $\begin{array}{l}\text { LC-TOFMS } \\
\text { suggested } \\
\text { formula }\end{array}$ & $\begin{array}{r}\text { Error } \\
(\mathrm{ppm})\end{array}$ & $\begin{array}{c}\text { AMS } \\
\text { measured } \\
{[\mathrm{M}-\mathrm{OH}]^{+}}\end{array}$ & $\begin{array}{l}\text { AMS } \\
\text { suggested } \\
\text { formula }\end{array}$ & Structure & \\
\hline \multicolumn{9}{|c|}{ Products of ISO or DMB } \\
\hline $\begin{array}{l}\text { Series } \\
1 \mathrm{~A}\end{array}$ & $\begin{array}{l}1 \\
2 \\
3 \\
4 \\
5\end{array}$ & $\begin{array}{l}119.0349 \\
221.0665 \\
323.0978 \\
425.1281 \\
527.1582\end{array}$ & $\begin{array}{l}\mathrm{C}_{4} \mathrm{H}_{7} \mathrm{O}_{4}^{-} \\
\mathrm{C}_{8} \mathrm{H}_{13} \mathrm{O}_{7}^{-} \\
\mathrm{C}_{12} \mathrm{H}_{19} \mathrm{O}_{10}^{-} \\
\mathrm{C}_{16} \mathrm{H}_{25} \mathrm{O}_{13}^{-} \\
\mathrm{C}_{20} \mathrm{H}_{31} \mathrm{O}_{16}^{-}\end{array}$ & $\begin{array}{r}8.5 \\
4.2 \\
1.6 \\
-2.0 \\
-4.7\end{array}$ & $\begin{array}{l}103 \\
205\end{array}$ & $\begin{array}{l}\mathrm{C}_{4} \mathrm{H}_{7} \mathrm{O}_{3}^{+} \\
\mathrm{C}_{8} \mathrm{H}_{13} \mathrm{O}_{6}^{+}\end{array}$ & & $\mathrm{T}_{n-1}^{\mathrm{OH}}$ \\
\hline $\begin{array}{l}\text { Series } \\
2 \mathrm{~A}\end{array}$ & $\begin{array}{l}1 \\
2 \\
3 \\
4 \\
5\end{array}$ & $\begin{array}{l}\text { ND } \\
266.0515 \\
368.0832 \\
470.1149 \\
572.1464\end{array}$ & $\begin{array}{l}\mathrm{C}_{8} \mathrm{H}_{12} \mathrm{NO}_{9}^{-} \\
\mathrm{C}_{12} \mathrm{H}_{18} \mathrm{NO}_{12}^{-} \\
\mathrm{C}_{16} \mathrm{H}_{24} \mathrm{NO}_{15}^{-} \\
\mathrm{C}_{20} \mathrm{H}_{30} \mathrm{NO}_{18}^{-}\end{array}$ & $\begin{array}{l}3.2 \\
2.3 \\
1.8 \\
1.2\end{array}$ & & & & \\
\hline $\begin{array}{l}\text { Series } \\
3 \mathrm{~A}^{\mathrm{a}}\end{array}$ & $\begin{array}{l}1 \\
2 \\
3 \\
4 \\
5\end{array}$ & $\begin{array}{l}\text { ND } \\
249.0615 \\
351.0928 \\
453.1245 \\
555.1560\end{array}$ & $\begin{array}{l}\mathrm{C}_{9} \mathrm{H}_{13} \mathrm{O}_{8}^{-} \\
\mathrm{C}_{13} \mathrm{H}_{19} \mathrm{O}_{11}^{-} \\
\mathrm{C}_{17} \mathrm{H}_{25} \mathrm{O}_{14}^{-} \\
\mathrm{C}_{21} \mathrm{H}_{31} \mathrm{O}_{17}^{-}\end{array}$ & $\begin{array}{l}4.0 \\
1.7 \\
1.4 \\
0.8\end{array}$ & $\begin{array}{l}131 \\
233\end{array}$ & $\begin{array}{l}\mathrm{C}_{5} \mathrm{H}_{7} \mathrm{O}_{4}^{+} \\
\mathrm{C}_{9} \mathrm{H}_{13} \mathrm{O}_{7}^{+}\end{array}$ & & -1 \\
\hline $\begin{array}{l}\text { Series } \\
4 A^{b}\end{array}$ & $\begin{array}{l}1 \\
2 \\
3 \\
4 \\
5\end{array}$ & $\begin{array}{l}\text { ND } \\
263.0768 \\
365.1080 \\
467.1394 \\
569.1706\end{array}$ & $\begin{array}{l}\mathrm{C}_{10} \mathrm{H}_{15} \mathrm{O}_{8}^{-} \\
\mathrm{C}_{14} \mathrm{H}_{21} \mathrm{O}_{11}^{-} \\
\mathrm{C}_{18} \mathrm{H}_{27} \mathrm{O}_{14}^{-} \\
\mathrm{C}_{22} \mathrm{H}_{33} \mathrm{O}_{17}^{-}\end{array}$ & $\begin{array}{r}2.5 \\
0.4 \\
-0.3 \\
-1.1\end{array}$ & $\begin{array}{l}145 \\
247\end{array}$ & $\begin{array}{l}\mathrm{C}_{6} \mathrm{H}_{9} \mathrm{O}_{4}^{+} \\
\mathrm{C}_{10} \mathrm{H}_{15} \mathrm{O}_{7}^{+}\end{array}$ & H & \\
\hline $\begin{array}{l}\text { Series } \\
5 \mathrm{~A}^{\mathrm{c}} \\
\text { (Newly } \\
\text { found) }\end{array}$ & $\begin{array}{l}1 \\
2 \\
3 \\
4\end{array}$ & $\begin{array}{l}\text { ND } \\
327.0683 \\
429.0989 \\
531.1302 \\
\end{array}$ & $\begin{array}{l}\mathrm{C}_{9} \mathrm{H}_{15} \mathrm{~N}_{2} \mathrm{O}_{11}^{-} \\
\mathrm{C}_{13} \mathrm{H}_{21} \mathrm{~N}_{2} \mathrm{O}_{14}^{-} \\
\mathrm{C}_{17} \mathrm{H}_{27} \mathrm{~N}_{2} \mathrm{O}_{17}^{-}\end{array}$ & $\begin{array}{r}3.9 \\
0.4 \\
-0.4\end{array}$ & & & & \\
\hline \multicolumn{9}{|c|}{ Products of BD } \\
\hline $\begin{array}{l}\text { Series } \\
1 \mathrm{~B}\end{array}$ & $\begin{array}{l}1 \\
2 \\
3 \\
4 \\
5\end{array}$ & $\begin{array}{l}105.0181 \\
193.0336 \\
281.0491 \\
369.0650 \\
457.0819\end{array}$ & $\begin{array}{l}\mathrm{C}_{3} \mathrm{H}_{5} \mathrm{O}_{4}^{-} \\
\mathrm{C}_{6} \mathrm{H}_{9} \mathrm{O}_{7}^{-} \\
\mathrm{C}_{9} \mathrm{H}_{13} \mathrm{O}_{10}^{-} \\
\mathrm{C}_{12} \mathrm{H}_{17} \mathrm{O}_{13}^{-} \\
\mathrm{C}_{15} \mathrm{H}_{21} \mathrm{O}_{16}^{-}\end{array}$ & $\begin{array}{l}-1.3 \\
-3.5 \\
-4.4 \\
-3.7 \\
-1.1\end{array}$ & $\begin{array}{c}89 \\
177 \\
265\end{array}$ & $\begin{array}{l}\mathrm{C}_{3} \mathrm{H}_{5} \mathrm{O}_{3}^{+} \\
\mathrm{C}_{6} \mathrm{H}_{9} \mathrm{O}_{6}^{+} \\
\mathrm{C}_{9} \mathrm{H}_{13} \mathrm{O}_{9}^{+}\end{array}$ & 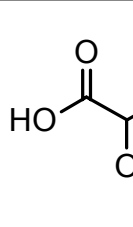 & $\begin{array}{c}\mathrm{OH} \\
n-1\end{array}$ \\
\hline $\begin{array}{l}\text { Series } \\
5 \mathrm{~B} \\
\text { (Newly } \\
\text { found) }\end{array}$ & $\begin{array}{l}1 \\
2 \\
3 \\
4 \\
5\end{array}$ & $\begin{array}{l}\text { ND } \\
299.0364 \\
387.0516 \\
475.0681 \\
563.0844\end{array}$ & $\begin{array}{l}\mathrm{C}_{7} \mathrm{H}_{11} \mathrm{~N}_{2} \mathrm{O}_{11}^{-} \\
\mathrm{C}_{10} \mathrm{H}_{15} \mathrm{~N}_{2} \mathrm{O}_{14}^{-} \\
\mathrm{C}_{13} \mathrm{H}_{19} \mathrm{~N}_{2} \mathrm{O}_{17}^{-} \\
\mathrm{C}_{16} \mathrm{H}_{23} \mathrm{~N}_{2} \mathrm{O}_{20}^{-}\end{array}$ & $\begin{array}{r}2.2 \\
-0.2 \\
0.6 \\
0.9\end{array}$ & & & 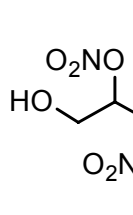 & \\
\hline
\end{tabular}

${ }^{a}$ This oligoester series involves esterification with formic acid. ${ }^{b}$ This oligoester series involves esterification with acetic acid. ${ }^{c}$ This series was only produced by the reaction of isoprene and was not produced by the reaction of DMB.

results of the experiment with 1,3-butadiene (EPA1094W) are shown in Fig. 6c. Mass signals were detected at these predicted mass numbers, but the peaks are not as strong when compared with the oligoester mass signals observed in the experiments with isoprene.
Values of $\mathrm{m} / \mathrm{z}$ measured for oligomers by ToF-AMS in $\mathrm{V}$ mode were compared with those calculated assuming chemical formulae shown in Table 2 . An each measured $\mathrm{m} / \mathrm{z}$ value agreed with a calculated value within $\mathrm{m} / \mathrm{z}$ of 0.04 . 


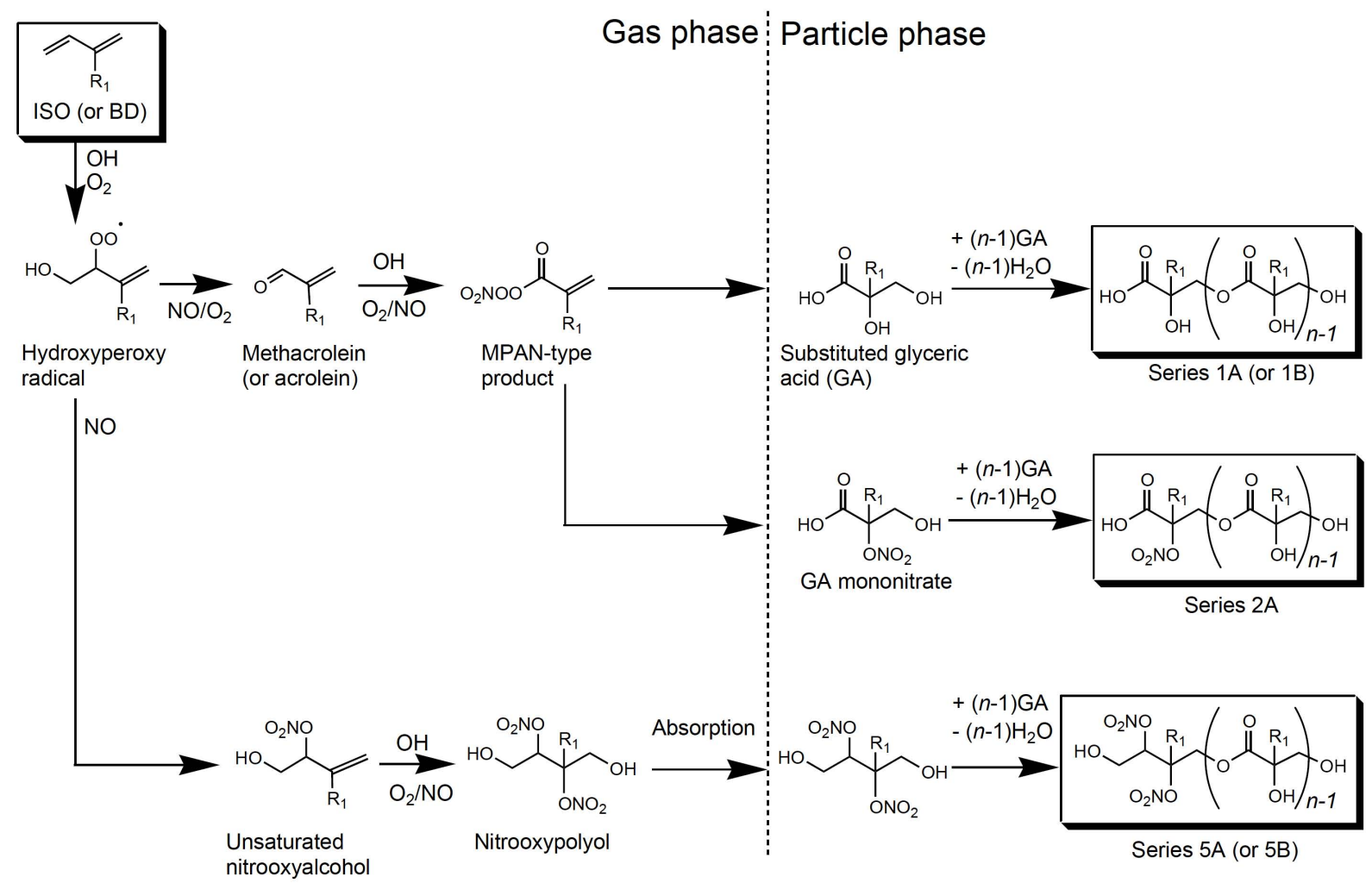

Fig. 7. Proposed mechanism of particle-phase product formation from the photooxidation of isoprene and 1,3-butadiene in the presence of $\mathrm{NO}_{\mathrm{x}} \cdot R_{1}$ is a methyl group (isoprene) or a hydrogen atom (1,3-butadiene).

\section{Reaction mechanism}

\subsection{Isoprene and 1,3-butadiene}

The proposed mechanism of oligomer formation from the reactions of isoprene and 1,3-butadiene is shown in Fig. 7. In the figure, $R_{1}$ represents a methyl group or a hydrogen atom for the reaction of isoprene or 1,3-butadiene, respectively. The atmospheric oxidation of isoprene proceeds through the reaction with $\mathrm{OH}$ radicals, $\mathrm{NO}_{3}$ radicals, and $\mathrm{O}_{3}$ although the major daytime oxidant is the $\mathrm{OH}$ radical (Yokouchi, 1994). Hydroxyperoxy radicals formed from the $\mathrm{OH}+$ isoprene reaction react with NO to form methacrolein (e.g. Miyoshi et al., 1994) and unsaturated nitrooxyalcohols (Chen et al., 1998; Lockwood et al., 2010). The subsequent oxidation of methacrolein produces peroxymethacryloyl nitrate (MPAN); it is suggested that this product undergoes subsequent oxidation to form 2-methylglyceric acid and 2-methylglyceric acid mononitrate in the particle phase (Surratt et al., 2010; Chan et al., 2010). Subsequent oxidation of nitrooxyalcohols leads to the formation of nitrooxypolyols, which are then absorbed into the particle phase (Sato, 2008).

2-Methylglyceric acid contains both a hydroxyl and a carboxyl group. The dehydration reaction between the hydroxyl group of one molecule and the carboxyl group of another molecule produces ester dimers. Successive condensation reactions result in the formation of oligomers of series $1 \mathrm{~A}$ (Surratt et al., 2006). Oligomers of series 2A are produced when one of these monomers is 2-methylglyceric acid mononitrate. The condensation reactions between oligomers of series $1 \mathrm{~A}$ and formic acid (or acetic acid) form oligomers of series $3 \mathrm{~A}$ (or those of series $4 \mathrm{~A}$ ). Oligomers of series $5 \mathrm{~A}$ are produced by the condensation reaction between nitrooxypolyols and 2-methylglyceric acid monomer or its oligomer.

Oligomers of series $1 \mathrm{~B}$ and $5 \mathrm{~B}$, found during the reaction of 1,3-butadiene, are produced through similar reactions to those resulting in the formation of $1 \mathrm{~A}$ and $5 \mathrm{~A}$ oligomers, respectively. Oligomers corresponding to series $2 \mathrm{~A}, 3 \mathrm{~A}$, and $4 \mathrm{~A}$ were not detected in the reaction of 1,3-butadiene.

\subsection{Isoprene- $1-{ }^{13} \mathrm{C}$ and DMB}

The photooxidation of isoprene- $1-{ }^{13} \mathrm{C}$ produces ${ }^{13} \mathrm{C}$ atom labeled methacrolein and non ${ }^{13} \mathrm{C}$ labeled methyl vinyl ketone (Fig. 8a). According to the proposed mechanism, 2methylglyceric acid monomer is produced by the reaction of methacrolein. If this is the case, then the ${ }^{13} \mathrm{C}$ atom is involved in the production of every $\mathrm{C}_{4}$ monomer. Actually, the regular mass difference of all $1 \mathrm{~A}-5 \mathrm{~A}$ oligomers found in the experiment with isoprene $-{ }^{13} \mathrm{C}$ was $103 \mathrm{amu}$, which is $1 \mathrm{amu}$ larger than that observed in the reaction of isoprene (Fig. 4a and c). In addition, mass differences between monomer and 
(a)
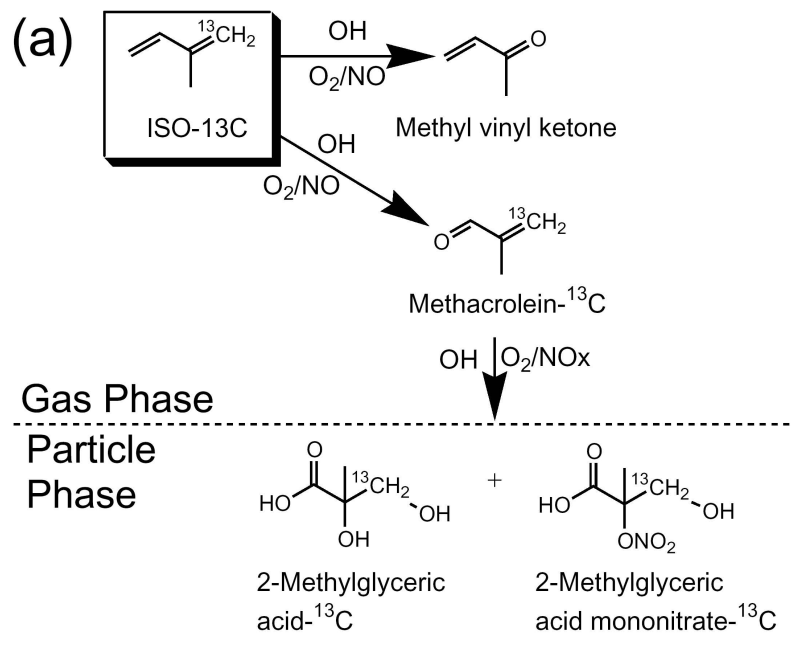

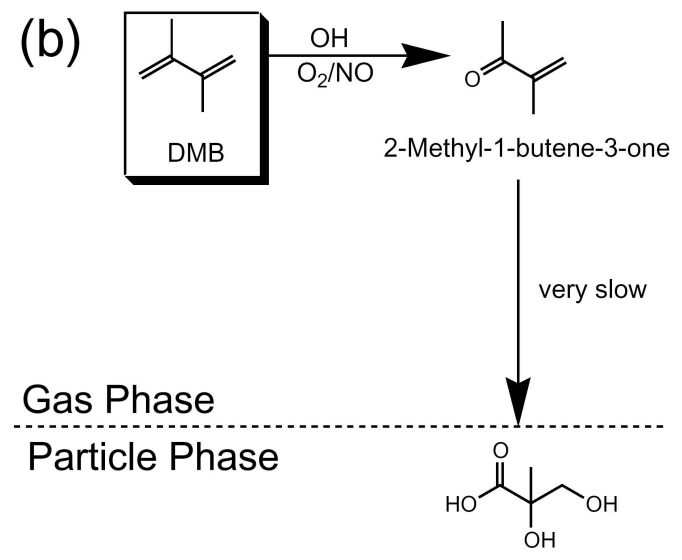

2-Methylglyceric acid

Fig. 8. Proposed mechanism of (a) isoprene-1- ${ }^{13} \mathrm{C}$ and (b) DMB photooxidation in the presence of $\mathrm{NO}_{\mathrm{X}}$.

dimer observed by ToF-AMS were also 103 amu (Fig. 6b). These results support the proposed mechanism in which the gaseous intermediate of oligoester formation is assumed to be methacrolein.

The unsaturated ketone (2-methyl-1-butene-3-one) is produced as a primary product of DMB oxidation; however, no unsaturated aldehyde is produced from DMB oxidation. Oligomers of series 1A-4A were found to be present in SOA particles from DMB (Fig. 4e). These oligomers would be produced by the oxidation of 2-methyl-1-butene-3-one or the oxidation of isoprene impurity. If we assume that 2methylglyceric acid is produced by the reaction of 2-methyl1-butene-3-one, a ketone group needs to be converted to a carboxyl group. However, the oxidation of a ketone group is very slow. This is congruent with the small yield of SOA from photooxidation of DMB since unsaturated aldehydes are not produced as primary products. The present result of DMB is consistent with the prior observation that the methacrolein gas-phase oxidation forms SOA but that of methyl vinyl ketone does not (Kroll et al., 2005; Surratt et al., 2006).

\section{Check of proposed mechanism}

\subsection{Low mass loading experiment}

Oligoesters are produced through gas/particle absorption of semi-volatile compounds followed by particle-phase oligomerization. Since the equilibrium of gas/particle partitioning is determined by existing particle mass concentration, the concentration of oligoesters produced will depend on the SOA mass loading in the reactor. Most previous studies have detected the presence of oligomers in SOA particles under higher mass loading conditions than ambient levels (e.g. Dommen et al., 2006; Surratt et al.,
2006). However, the AMS identification of oligomers in isoprene $+\mathrm{OH}$ SOA under low aerosol loadings (1.7$9.3 \mu \mathrm{g} \mathrm{m}^{-3}$ ) was also carried out by Kroll et al. (2006). In this study, we investigate whether or not oligomers can be detected at ambient particle levels using our environmental chamber designed for low-concentration experiments. SOA mass loading was controlled by changing the initial isoprene concentration between 20 and $573 \mathrm{ppb}$, while maintaining the initial isoprene/ $\mathrm{NO}_{\mathrm{x}}$ ratio within the range 0.6-0.9 (EPA1058W, EPA1058E, EPA1060W, EPA1060E, EPA1061W, and EPA1061E). Figure 9 shows the oligomer distribution for series 1A, 2A, and 5A. Signals of $1 \mathrm{~A}-5 \mathrm{~A}$ oligomers were detected even at the lowest SOA mass loading of all six experiments. These results confirm that semi-volatile compounds resulting in oligoester formation are sufficiently absorbed into the particle phase even at $3 \mu \mathrm{g} \mathrm{m}^{-3}$ of SOA mass loading.

\subsection{Time profiles of oligomers}

According to the proposed mechanism, oligoesters are produced by successive condensation reactions of 2 methylglyceric acid in the particle phase. In a previous study, concentrations of oligomers at different degrees of oligomerization were monitored by AMS to examine particle-phase oligomerization (Surratt et al., 2006). Time profiles of oligoesters were also monitored by ToF-AMS in this study. Figure 10a shows the time profiles of $m / z 103$ and 205 signals measured by ToF-AMS in the experiment with isoprene (EPA1070W). The monitored signals correspond to monomers and dimers of series 1A. No clear difference was observed between the time profiles of monomers and dimers after $150 \mathrm{~min}$. Trimer or higher oligomers were not detected, probably because these oligomers undergo dissociative ionization during the EI process of ToF-AMS in this study. Therefore, monomer and dimer signals measured by 

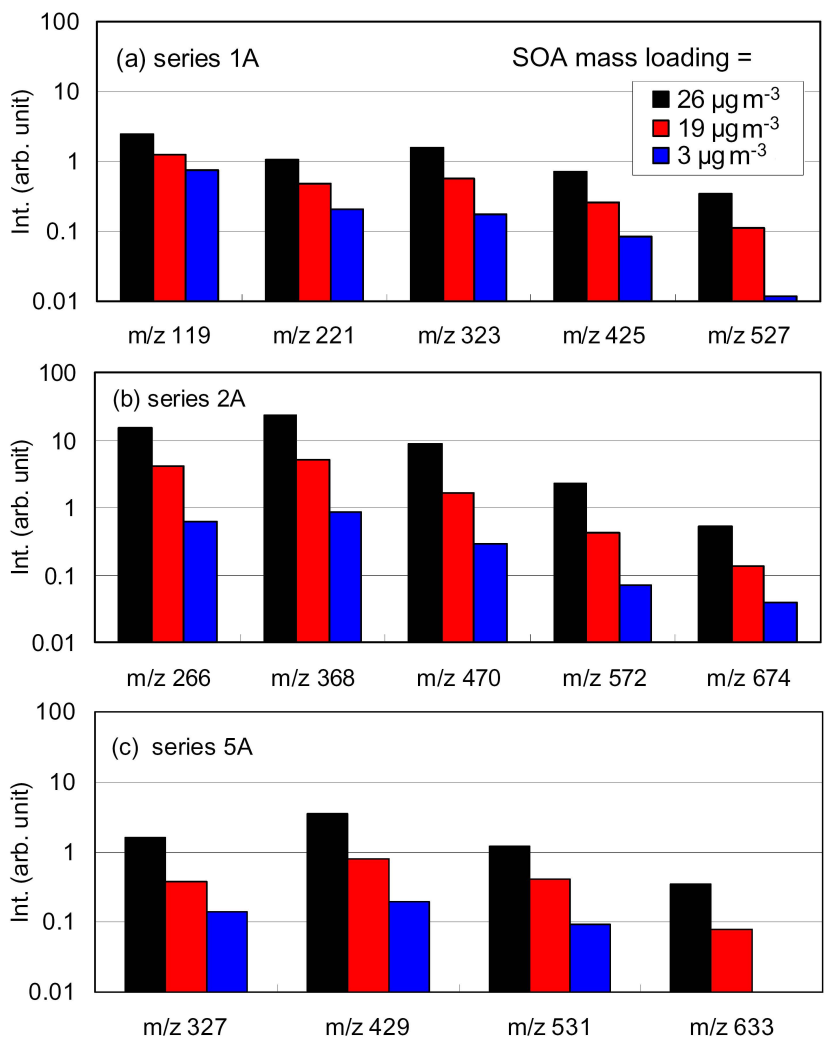

Fig. 9. Oligomer distribution measured in experiments with isoprene (EPA1058E, EPA1060E, and EPA1061E). SOA mass loading was changed between 3 and $26 \mu \mathrm{g} \mathrm{m}^{-3}$ by changing the initial reactant concentrations, maintaining the isoprene/ $/ \mathrm{NO}_{\mathrm{x}}$ ratio within the range $0.6-0.9$.

ToF-AMS are significantly affected by fragment ions formed from the ionization of higher oligomers.

Time profiles of particle-phase products have also been studied by analyzing multiple off-line samples collected at different reaction times (e.g. Hatakeyama et al., 1985; Jang and Kamens, 2001). We collected hourly filter samples (6 total) to study the time profiles of oligomers in an isoprene experiment (EPA1078E). The concentrations of 2methylglyceric acid monomer and its oligomers, determined by LC-TOFMS analysis, are plotted as a function of time (Fig. 10b); the vertical axis is the relative concentration on a linear scale. Each determined concentration value involves about $15 \%$ of uncertainty, mainly resulting from the uncertainty of recovery during sample extraction. The concentrations of monomer $(\mathrm{m} / \mathrm{z}, 119)$ and dimer $(\mathrm{m} / \mathrm{z} 221)$ increased above detectable levels at $60-120 \mathrm{~min}$, and continued to increase until 180-240 min. After that, these concentrations maintained a constant level or decreased slightly. In contrast, the concentrations of trimer or higher oligomers increased monotonically with time. These results indicate that the production of trimer or higher oligomers is competitive with monomer and dimer formation after $180-240 \mathrm{~min}$. In other
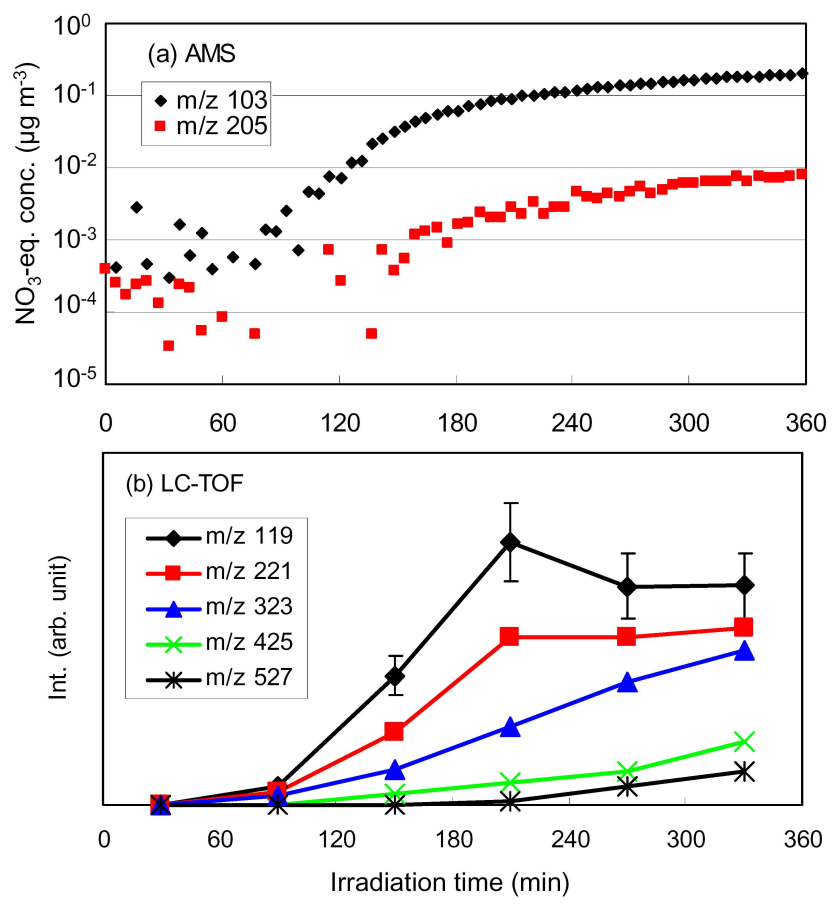

Fig. 10. Time profiles of particulate product mass signals measured by (a) ToF-AMS during an experiment with isoprene (EPA1070W) and (b) LC-TOFMS during an experiment with isoprene (EPA1078E).

words, oligoesters are produced by particle-phase successive reactions as assumed in the proposed mechanism.

\subsection{Lights-off experiment}

According to the proposed mechanism, 2-methylglyceric acid is produced by reactions initiated by the gas-phase $\mathrm{OH}+$ methacrolein reaction. If this is the case, no 2methylglyceric acid monomer is produced in the absence of irradiation. In order to study the lights-off effect, we conducted experiments with isoprene in which black lights were turned off after $178 \mathrm{~min}$ of irradiation time (EPA1090W and EPA1090E). The results of EPA1090W are shown in Fig. 11. When the lights were turned off, PTR-MS results showed that most of the isoprene $(\mathrm{m} / \mathrm{z} 69)$ was consumed by the reaction, whereas a substantial amount of methacrolein and methyl vinyl ketone $(\mathrm{m} / \mathrm{z} 71)$ was still present in the reaction system (Fig. 11a). The slope of $m / z 71$ does not greatly change when the lights are turned off. The loss of $m / z 71$ in the dark will be caused by the reactions with $\mathrm{O}_{3}$ and $\mathrm{NO}_{3}$. The $\mathrm{O}_{3}$ level when the lights were turend off was about $300 \mathrm{ppb}$. This $\mathrm{O}_{3}$ concentration was confirmed to be high enough to explain the loss rate of $\mathrm{m} / \mathrm{z} 71$ in the dark; the loss rate of methyl vinyl ketone was $3.2 \times 10^{-5} \mathrm{~s}^{-1}$; the loss rate of methacrolein was $8.2 \times 10^{-6} \mathrm{~s}^{-1}$; where the rate constants measured by Treacy et al. (1992) were used. 

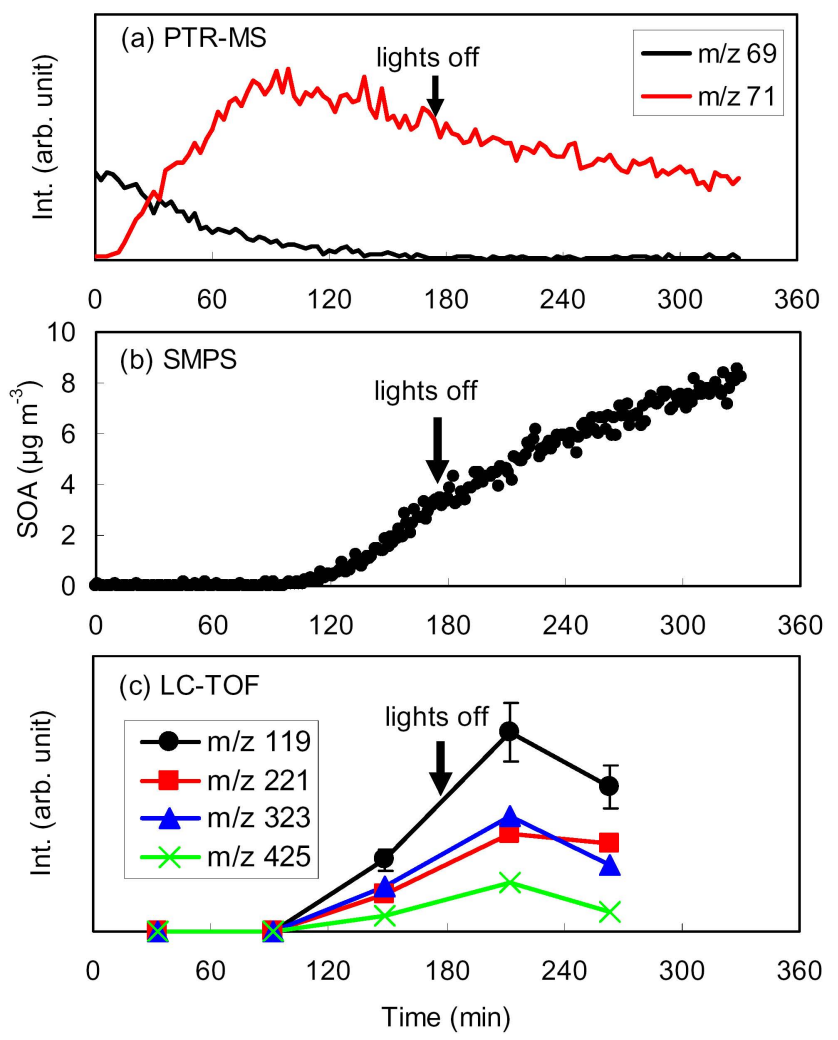

Fig. 11. Time profiles of (a) PTR-MS signals, (b) SOA mass concentration, and (c) LC-TOFMS oligomer mass signals measured in a lights-off experiment with isoprene (EPA1090W).

When the lights are turned off, SOA particles had already been produced (Fig. 11b). The SOA concentration increased even after the lights were turned off, suggesting that SOA is formed from the reactions of gaseous oxidation products with $\mathrm{NO}_{3}$ radicals or $\mathrm{O}_{3}$ during this period. The filter was changed every $60 \mathrm{~min}$, and five SOA filter samples in total were collected during this experiment (Fig. 11c). Again, the concentration data involved about $15 \%$ uncertainty. Monomer and all detected oligomers (i.e. dimer, trimer, and tetramer) increased until the lights were turned off. After the lights were turned off, the concentrations of monomer and oligomers were maintained at constant values or decreased slightly with time; these results are slightly different from those of the irradiated experiments in which trimer and tetramer concentrations increased monotonically with time. Pentamer was not detected in the lights-off experiment. Oligoester formation was suppressed when the lights were turned off, which is consistent with the proposed mechanism.

If oligomer formation in the particle phase involves successive reactions, the concentration of the monomer might decrease more rapidly than that of a higher oligomer immediately after the lights were turned off. However, no such result was obtained. After the lights are turned off, the reactions of isoprene oxidation products with $\mathrm{O}_{3}$ and $\mathrm{NO}_{3}$ occur to form SOA. Particulate 2-methylglyceric acid is known to be produced by the $\mathrm{O}_{3}+$ isoprene reaction (Kleindienst et al., 2007). Formation of the 2-methylglyceric acid monomer by the reaction with $\mathrm{O}_{3}$ would affect the oligomer time profiles in the dark.

A new product signal was found at $m / z 509$ by LC-TOFMS analysis in samples collected after the lights were turned off. The accurate mass of these ions was $509.0859 \mathrm{amu}$; the suggested ion formula is $\mathrm{C}_{12} \mathrm{H}_{21} \mathrm{~N}_{4} \mathrm{O}_{18}^{-}$. The same product was observed in SOA formed from the $\mathrm{NO}_{3}+$ isoprene reaction ( $\mathrm{Ng}$ et al., 2008). This product is therefore likely produced by the reaction of an isoprene oxidation product with $\mathrm{NO}_{3}$ radical.

\section{Temperature dependence}

In this study, experiments with isoprene were conducted at $300 \mathrm{~K}$ (EPA1078W and EPA1078E) and $278 \mathrm{~K}$ under similar reactant concentration conditions (EPA1148W and EPA1148E). $\mathrm{NO}_{2}$ photolysis rates in experiments at 300 and $278 \mathrm{~K}$ were set to $0.12 \mathrm{~min}^{-1}$. Initial isoprene concentrations of experiments at $300 \mathrm{~K}$ (EPA1078W) and $278 \mathrm{~K}$ (EPA1048W) were 115 and 132 ppb, respectively (Fig. 12a). The SOA yield measured at $278 \mathrm{~K}(0.105-0.152)$ was about 2-3 times as high as that measured at $300 \mathrm{~K}(0.047-0.053)$, as shown in Fig. 12b. Even though oligomerization occurs in the particle phase, the temperature dependence of SOA yield is largely explained by the gas/particle partitioning of semivolatile compounds.

We measured the $373 \mathrm{~K}$ VFR in the experiments at 300 and $278 \mathrm{~K}$, and confirmed the VFR was independent of the particle diameter. If the temperature dependence of SOA yield $(Y)$ is purely determined by the gas/particle partitioning of semi-volatile compounds, the $\operatorname{VFR}(300 \mathrm{~K}) / \mathrm{VFR}(278 \mathrm{~K}) \mathrm{ra}$ tio would be the same as the $Y(278 \mathrm{~K}) / Y(300 \mathrm{~K})$ ratio. Thus, a comparison of the temperature dependence of $Y$ with that of VFR will provide us information on the chemical conversion of aerosol constituents in the particle phase. In the present study, the $\operatorname{VFR}(300 \mathrm{~K})$ was $0.45-0.56$, whereas the VFR(278 K) was 0.26-0.43 (Fig. 12c). The change in SOA yield cannot be solely explained by changes in the VFR (SOA yield increased 2-3 times while the VFR changes by less than a factor of 2). Although the temperature dependence of SOA yield is largely explained by gas/particle partitioning of semi-volatile compounds, the VFR results support the present findings that oligoesters are formed in the particle phase.

The ratio of total peak area of nitrooxypolyol-involving oligoesters (series 5A) to the total peak area of other oligoesters (series 1A-4A) measured at $278 \mathrm{~K}$ increased compared with that at $300 \mathrm{~K}$. From GC-FID data, the methacrolein yields at 278 and $300 \mathrm{~K}$ were estimated, and the gaseous product yield was confirmed to be basically constant between 278 and $300 \mathrm{~K}$. This indicates that the observed 

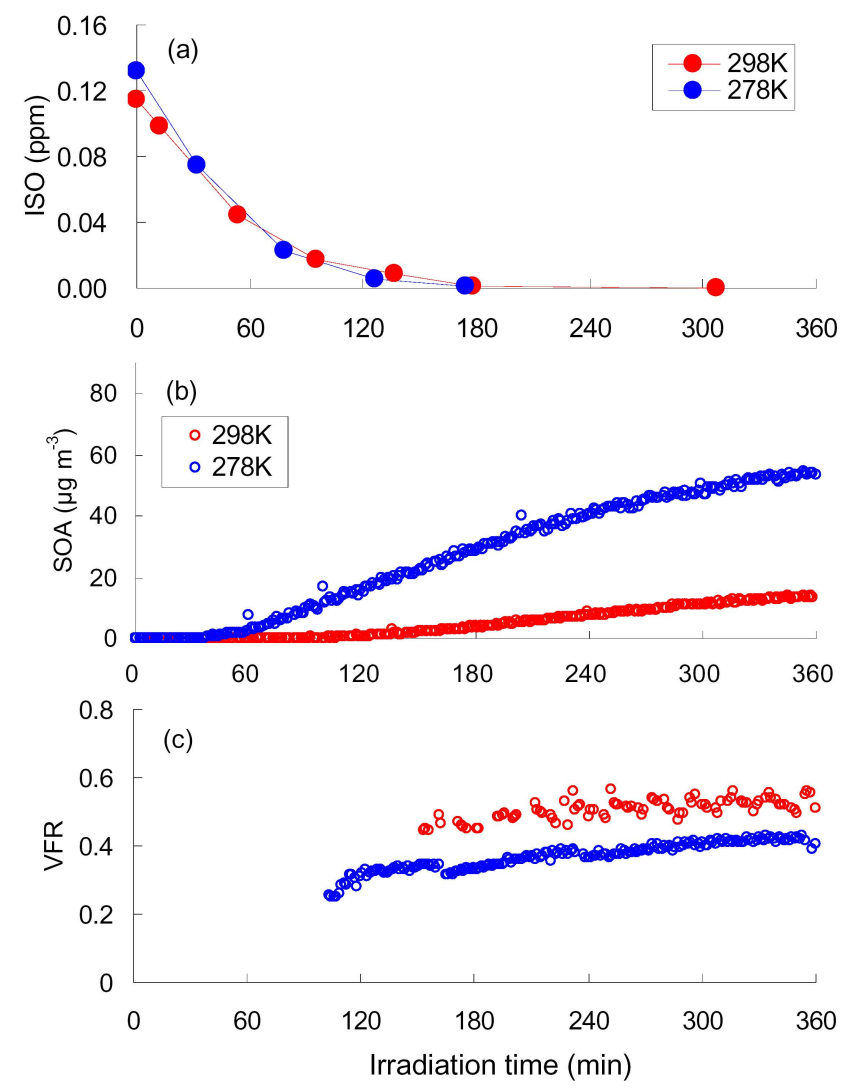

Fig. 12. Time profiles of (a) isoprene concentration, (b) SOA concentration, and (c) volume fraction remaining (VFR) measured during experiments with isoprene at $278 \mathrm{~K}$ (EPA1148W) and $300 \mathrm{~K}$ (EPA1078W). The $\mathrm{NO}_{2}$ photolysis rate for both experiments was set to $0.12 \mathrm{~min}^{-1}$.

temperature dependence of particulate chemical composition is mainly determined by the changes in gas/particle partitioning of semi-volatile compounds. The lower temperature will result in higher condencation of 2-methylglyceric acid precursors and much higher condensation of nitrooxypolyols.

Series $2 \mathrm{~A}$ and $5 \mathrm{~A}$ oligomers involving nitrooxy groups are expected to be detected as nitrates by high-resolution ToF-AMS. Therefore, the ratio of nitrates to organics $\left(\mathrm{HRNO}_{3} / \mathrm{HROrg}\right)$ measured by ToF-AMS at $278 \mathrm{~K}$ would be expected to be higher than $300 \mathrm{~K}$. This is confirmed as $\mathrm{HRNO}_{3} / \mathrm{HROrg}$ ratio measured at $278 \mathrm{~K}(0.07-0.14)$ was higher than $300 \mathrm{~K}(0.03-0.05)$. The lower temperature could result in higher condensation of $\mathrm{HNO}_{3}$. Despite the low relative humidity, organic acids can retain water and provide a medium for $\mathrm{HNO}_{3}$ to condense. We checked $\mathrm{HNO}_{3}$ condensation by the ToF-AMS signal ratio of $m / z 30$ to $\mathrm{m} / \mathrm{z} 46$. This ratio is $3-5$ for organic nitrates and $<3$ for inorganic nitrates (Rollins et al., 2009; Sato et al., 2010). The $\mathrm{m} / \mathrm{z} 30$ to $\mathrm{m} / \mathrm{z}$ 46 ratio at $300 \mathrm{~K}$ (EPA1078W) was $4.7 \pm 1.2$, whereas that at $278 \mathrm{~K}$ (EPA1148W) was $4.7 \pm 0.6$, indicating $\mathrm{HNO}_{3}$ is a minor particulate component both at 278 and $300 \mathrm{~K}$.

\section{Atmospheric implications}

The present results confirm that SOA is produced from the diene/ $/ \mathrm{NO}_{\mathrm{x}}$ photooxidation in which unsaturated aldehyde is formed as a gaseous intermediate; that is, 1,3-butadiene as well as isoprene is a possible SOA precursor in urban air. The present results also show that the yield of isoprene SOA increases with decreasing the temperature; that is, in ambient air the yield of isoprene SOA depends on the altitude, the latitude, the season, and etc. This finding will have a large impact when we evaluate a total amount of global SOA formation.

\section{Conclusions}

In this study, SOA formation from the photooxidation of isoprene, isoprene- $1-{ }^{13} \mathrm{C}, 1,3$-butadiene, and $\mathrm{DMB}$ was investigated under high $\mathrm{NO}_{\mathrm{x}}$ conditions. The SOA yield measured for the reaction of 1,3-butadiene was close to or slightly higher than that measured for the reaction of isoprene, suggesting that the photooxidation of 1,3-butadiene is a potential source of SOA in urban air. On the other hand, only a very small amount of SOA was produced during the photooxidation of DMB.

Off-line LC-TOFMS analysis revealed that the signals of the oligoesters identified comprise a major fraction $(0.10$ 0.33 ) of the signals of the SOA products observed from all dienes investigated. During the photooxidation of conjugated dienes under high $\mathrm{NO}_{\mathrm{x}}$ conditions, oligoesters are produced by a reaction of unsaturated aldehyde, which is a gas-phase oxidation product. The results of an experiment with isoprene- $1-{ }^{13} \mathrm{C}$ confirmed the proposed mechanism in which methacrolein is assumed to be a key intermediate of oligoester formation. This mechanism was also confirmed by the reaction of DMB: only a very small amount of SOA was produced during DMB photooxidation, in which no unsaturated aldehyde is formed.

Oligoesters produced by the dehydration reaction between nitrooxypolyol and 2-methylglyceric acid monomer or its oligomer (oligomer series 5A) were characterized in the experiments with isoprene. These oligomers are possible sources of 2-methyltetrols found in ambient aerosol samples collected under high $\mathrm{NO}_{\mathrm{x}}$ conditions.

The proposed mechanism was also checked by measurements of oligomer signals as functions of SOA mass loading and irradiation time. Oligoester formation was confirmed to occur even under low SOA mass loading conditions $\left(>3 \mu \mathrm{g} \mathrm{m}^{-3}\right)$. Time profiles of oligomers, measured by off-line analysis, suggested that oligomerization involves successive reactions as assumed in the proposed mechanism. Oligoester formation was suppressed when the lights were turned off. This result was consistent with the proposed mechanism although the result would be interfered by reactions with $\mathrm{O}_{3}$ in the dark. 
This is the first study to investigate the temperature dependence of SOA formation from isoprene photooxidation. The ratio of total chromatographic peak area of nitrooxypolyolinvolving oligoesters (series 5A) to total peak area of other oligoesters measured at $278 \mathrm{~K}$ increased compared to that at $300 \mathrm{~K}$. The SOA yield measured at $278 \mathrm{~K}$ was higher than that measured at $300 \mathrm{~K}$; the temperature dependence of SOA yield is largely explained by gas/particle partitioning of semivolatile compounds even though oligomerization occurs in the particle phase.

Acknowledgements. This work was supported by residential fellowships and sabbatical visitorships of the National Institute for Environmental Studies. The authors also thank National Science Foundation, ATM-091282, for additional experimental support.

Edited by: N. M. Donahue

\section{References}

Agrawal, H., Welch, W. A., Miller, J. W., and Cocker, D. R.: Emission measurements from a crude oil tanker at sea, Environ. Sci. Technol., 42, 7098-7103, 2008.

An, W. J., Pathak, R. K., Lee, B.-H., and Pandis, S. N.: Aerosol volatility measurement using an improved thermodenuder: Application to secondary organic aerosol, J. Aerosol Sci., 38, 305314, 2007.

Angove, D. E., Fookes, C. J. R., Hynes, R. G., Walters, C. K., and Azzi, M.: The characterization of secondary organic aerosol formed during the photodecomposition of 1,3-butadiene in air containing nitric oxide, Atmos. Enviorn., 40, 4597-4607, 2006.

Atkinson, R.: Kinetics and mechanisms of gas-phase reactions of the hydroxyl radical with organic compounds under atmospheric conditions, Chem. Rev., 86, 69-201, 1986.

Böge, O., Miao, Y., Plewka, A., and Herrmann, H.: Formation of secondary organic particle phase compounds from isoprene gasphase oxidation products: An aerosol chamber and field study, Atmos. Environ., 40, 2501-2509, 2006.

Bowman, F. M., Odum, J. R., Seinfeld, J. H., and Pandis, S. N.: Mathematical model for gas-particle partitioning of secondary organic aerosols, Atmos. Environ., 31, 3921-3931, 1997.

Calvert, J. G., Atkinson, R., Becker, K. H., Kamens, R. M., Seinfeld, J. H., Wallington, T. J., and Yarwood, G.: Importance of aromatic hydrocarbons in the chemistry of ozone generation in the urban atmosphere, in: The Mechanisms of Atmospheric Oxidation of Aromatic Hydrocarbons, Oxford University Press, New York, USA, 3-35, 2002.

Carlton, A. G., Lim, H.-J., Altieri, K., Seitinger, S., and Turpin, B. J.: Link between isoprene and SOA: fate of pyruvic acid in dilute aqueous solution, Geophys. Res. Lett., 33, L06822, doi:10.1029/2005GL025374, 2006.

Carlton, A. G., Wiedinmyer, C., and Kroll, J. H.: A review of Secondary Organic Aerosol (SOA) formation from isoprene, Atmos. Chem. Phys., 9, 4987-5005, doi:10.5194/acp-9-4987-2009, 2009.

Carter, W. P. L., Cocker III, D. R., Fitz, D. R., Malkina, I. L., Bumiller, K., Sauer, C. G., Pisano, J. T., Bufalino, C., and Song, C.: A new environmental chamber for evaluation of gas-phase chemical mechanisms and secondary organic aerosol formation, Atmos. Environ., 39, 7768-7788, 2005.

Chan, A. W. H., Kroll, J. H., Ng, N. L., and Seinfeld, J. H.: Kinetic modeling of secondary organic aerosol formation: effects of particle- and gas-phase reactions of semivolatile products, Atmos. Chem. Phys., 7, 4135-4147, doi:10.5194/acp-7-4135-2007, 2007.

Chan, A. W. H., Chan, M. N., Surratt, J. D., Chhabra, P. S., Loza, C. L., Crounse, J. D., Yee, L. D., Flagan, R. C., Wennberg, P. O., and Seinfeld, J. H.: Role of aldehyde chemistry and $\mathrm{NO}_{\mathrm{x}}$ concentrations in secondary organic aerosol formation, Atmos. Chem. Phys., 10, 7169-7188, doi:10.5194/acp-10-7169-2010, 2010.

Chen, X. H., Hulbert, D., and Shepson, P. B.: Measurement of the organic nitrate yield from $\mathrm{OH}$ reaction with isoprene, J. Geophys. Res., 103, 25563-25568, 1998.

Claeys, M., Graham, B., Vas, G., Wang, W., Vermeylen, R., Pashynska, V., Cafmeyer, J., Guyon, P., Andreae, M. O., Artaxo, P., and Maenhaut, W.: Formation of secondary organic aerosols through photooxidation of isoprene, Science, 303, 1173-1176, 2004a.

Claeys, M., Wang, W., Ion, A. C., Kourtchev, I., Gelencsér, A., and Maenhaut, W.: Formation of secondary organic aerosols from isoprene and its gas-phase oxidation products through reaction with hydrogen peroxide, Atmos. Environ., 38, 4093-4098, 2004b.

Claeys, M., Kourtchev, I., Pashynska, V., Vas, G., Vermeylen, R., Wang, W., Cafmeyer, J., Chi, X., Artaxo, P., Andreae, M. O., and Maenhaut, W.: Polar organic marker compounds in atmospheric aerosols during the LBA-SMOCC 2002 biomass burning experiment in Rondnia, Brazil: sources and source processes, time series, diel variations and size distributions, Atmos. Chem. Phys., 10, 9319-9331, doi:10.5194/acp-10-9319-2010, 2010.

Clements, A. and Seinfeld, J. H.: Detection and quantification of 2-methyltetrols in ambient aerosol in the southeastern United States, Atmos. Environ., 41, 1825-1830, 2007.

Cocker III, D. R., Flagan, R. C., and Seinfeld, J. H.: State-of-theart chamber facility for studying atmospheric aerosol chemistry, Environ. Sci. Technol., 35, 2594-2601, 2001.

Darer, A. I., Cole-Filipiak, N. C., O'Connor, A. E., and Elrod, M. J.: Formation and stability of atmospherically relevant isoprenederived organosulfates and organonitrates, Environ. Sci. Technol., 45, 1895-1902, 2011.

DeMore, W. B., Sander, S. P., Golden, D. M., Hampson, R. F., Kurylo, M. J., Howerd, C. J., Ravishankara, A. R., Kolb, C. E., and Molina, M. J.: Chemical Kinetics and Photochemical Data for Use in Stratospheric Modeling, JPL Publication 97-4, NASA Jet Propulsion Laboratory, Pasadena, USA, 1997.

Dommen, J., Metzger, A., Duplissy, J., Kalberer, M., Alfarra, M. R., Gascho, A., Weingartner, E., Prevot, A. S. H., Verheggen, B., and Baltensperger, U.: Laboratory observation of oligomers in the aerosol from isoprene/ $\mathrm{NO}_{\mathrm{x}}$ photooxidation, Geophys. Res. Lett., 33, L13805, doi:10.1029/2006GL026523, 2006.

Drewnick, F., Hings, S. S., DeCarlo, P. F., Jayne, J. T., Gonin, M., Fuhrer, K., Weimer, S., Jimenez, J. L., Demerjian, K. L., Borrmann, S., and Worsnop, D. R.: A new time-of-flight aerosol mass spectrometer (ToF-AMS) - instrument description and first field deployment, Aerosol Sci. Tech., 39, 637-658, 2005.

Edney, E. O., Kleindienst, T. E., Jaoui, M., Lewandowski, M., Offenberg, J. H., Wang, W., and Claeys, M.: Formation of 2-methyl tetrols and 2-methylglyceric acid in secondary organic aerosol 
from laboratory irradiated isoprene/ $\mathrm{NO}_{\mathrm{x}} / \mathrm{SO}_{2} /$ air mixtures and their detection in ambient $\mathrm{PM}_{2.5}$ samples collected in the eastern United States, Atmos. Enviorn., 39, 5281-5289, 2005.

Fu, P. Q., Kawamura, K., Chen, J., and Barrie, L. A.: Isoprene, monoterpene, and sesquiterpene oxidation products in the high arctic aerosols during late winter to early summer, Environ. Sci. Technol., 43, 4022-4028, 2009.

Fu, P. Q., Kawamura, K., Kanaya, Y., and Wang, Z.: Contributions of biogenic volatile organic compounds to the formation of secondary organic aerosols over Mt. Tai, Central East China, Atmos. Environ., 44, 4817-4826, 2010a.

Fu, P. Q., Kawamura, K., Pavuluri, C. M., Swaminathan, T., and Chen, J.: Molecular characterization of urban organic aerosol in tropical India: contributions of primary emissions and secondary photooxidation, Atmos. Chem. Phys., 10, 2663-2689, doi:10.5194/acp-10-2663-2010, 2010 b.

Gómez-González, Y., Surratt, J. D., Cuyckens, F., Szmigielski, R., Vermeylen, R., Jaoui, M., Lewandowski, M., Offenberg, J. H., Kleindienst, T. E., Edney, E. O., Blockhuys, F., Van Alsenoy, C., Maenhaut, W., and Claeys, M.: Characterization of organosulfates from the photooxidation of isoprene and unsaturated fatty acids in ambient aerosol using liquid chromatography/(-)electrospray ionization mass spectrometry, J. Mass Spectrom., 43, 371-382, 2008.

Guenther, A., Karl, T., Harley, P., Wiedinmyer, C., Palmer, P. I., and Geron, C.: Estimates of global terrestrial isoprene emissions using MEGAN (Model of Emissions of Gases and Aerosols from Nature), Atmos. Chem. Phys., 6, 3181-3210, doi:10.5194/acp-63181-2006, 2006.

Hallquist, M., Wenger, J. C., Baltensperger, U., Rudich, Y., Simpson, D., Claeys, M., Dommen, J., Donahue, N. M., George, C., Goldstein, A. H., Hamilton, J. F., Herrmann, H., Hoffmann, T., Iinuma, Y., Jang, M., Jenkin, M. E., Jimenez, J. L., Kiendler-Scharr, A., Maenhaut, W., McFiggans, G., Mentel, Th. F., Monod, A., Prévôt, A. S. H., Seinfeld, J. H., Surratt, J. D., Szmigielski, R., and Wildt, J.: The formation, properties and impact of secondary organic aerosol: current and emerging issues, Atmos. Chem. Phys., 9, 5155-5236, doi:10.5194/acp-95155-2009, 2009.

Hatakeyama, S., Tanonaka, T., Weng, J. H., Bandow, H., Takagi, H., and Akimoto, H.: Ozone cyclohexene reaction in air-quantitative analysis of particulate products and the reaction mechanism, Environ. Sci. Technol., 19, 935-942, 1985.

Henze, D. K. and Seinfeld, J. H.: Global secondary organic aerosol from isoprene oxidation, Geophys. Res. Lett., 33, L09812, doi:10.1029/2006GL025976, 2006.

Henze, D. K., Seinfeld, J. H., Ng, N. L., Kroll, J. H., Fu, T.-M., Jacob, D. J., and Heald, C. L.: Global modeling of secondary organic aerosol formation from aromatic hydrocarbons: highvs. low-yield pathways, Atmos. Chem. Phys., 8, 2405-2420, doi:10.5194/acp-8-2405-2008, 2008.

Jang, M. and Kamens, R. M.: Characterization of secondary aerosol from the photooxidation of toluene in the presence of $\mathrm{NO}_{\mathrm{x}}$ and 1-propene, Environ. Sci. Technol., 35, 3626-3639, 2001.

Jang, M., Czoschke, N. M., Lee, S., and Kamens, R. M.: Heterogeneous atmospheric aerosol production by acid-catalyzed particlephase reactions, Science, 298, 814-817, 2002.
Jeffries, H. E.: Photochemical air pollution, in: Composition, Chemistry, and Climate of the Atmosphere, Van Nostrand Reinhold, New York, USA, 308-348, 1995.

Jemma, C. A., Shore, P. R., and Widdicombe, K. A.: Analysis of $\mathrm{C}_{1}-\mathrm{C}_{16}$ hydrocarbons using dual-column capillary GC: Application to exhaust emissions from passenger car and motorcycle engines, J. Chromatogr. Sci., 33, 34-48, 1995.

Kleindienst, T. E., Lewandowski, M. L., Offenberg, J. H., Jaoui, M., and Edney, E. O.: Ozone-isoprene reaction: Re-examination of the formation of secondary organic aerosol, Geophys. Res. Lett., 34, L01805, doi:10.1029/2006GL027485, 2007.

Kleindienst, T. E., Lewandowski, M., Offenberg, J. H., Jaoui, M., and Edney, E. O.: The formation of secondary organic aerosol from the isoprene $+\mathrm{OH}$ reaction in the absence of $\mathrm{NO}_{\mathrm{x}}$, Atmos. Chem. Phys., 9, 6541-6558, doi:10.5194/acp-9-6541-2009, 2009.

Kroll, J. H. and Seinfeld, J. H.: Chemistry of secondary organic aerosol: formation and evolution of low-volatility organics in the atmosphere, Atmos. Environ., 42, 3593-3624, 2008.

Kroll, J. H., Ng, N. L., Murphy, S. M., Flagan, R. C., and Seinfeld, J. H.: Secondary organic aerosol formation from isoprene photooxidation under high- $\mathrm{NO}_{\mathrm{x}}$ conditions, Geophys. Res. Lett., 32, L18808, doi:10.1029/2005GL023637, 2005.

Kroll, J. H., Ng, N. L., Murphy, S. M., Flagan, R. C., and Seinfeld, J. H.: Secondary organic aerosol formation from isoprene photooxidation, Environ. Sci. Technol., 40, 1869-1877, 2006.

Liu, Y., Shao, M., Fu, L., Lu, S., Zeng, L., and Tang, D.: Source profiles of volatile organic compounds (VOCs) measured in China: Part I, Atmos. Environ., 42, 6247-6260, 2008.

Lockwood, A. L., Shepson, P. B., Fiddler, M. N., and Alaghmand, M.: Isoprene nitrates: preparation, separation, identification, yields, and atmospheric chemistry, Atmos. Chem. Phys., 10, 6169-6178, doi:10.5194/acp-10-6169-2010, 2010.

Malloy, Q. G. J., Li Qi, Warren, B., Cocker III, D. R., Erupe, M. E., and Silva, P. J.: Secondary organic aerosol formation from primary aliphatic amines with $\mathrm{NO}_{3}$ radical, Atmos. Chem. Phys., 9, 2051-2060, doi:10.5194/acp-9-2051-2009, 2009.

Miyoshi, A., Hatakeyama, S., and Washida, N.: OH radicalinitiated photooxidation of isoprene: an estimate of global CO production, J. Geophys. Res., 99, 18779-18787, 1994.

Nelson, P. F., Tibbett, A. R., and Day, S. J.: Effects of vehicle type and fuel quality on real world toxic emissions from diesel vehicles, Atmos. Environ., 42, 5291-5303, 2008.

Ng, N. L., Kwan, A. J., Surratt, J. D., Chan, A. W. H., Chhabra, P. S., Sorooshian, A., Pye, H. O. T., Crounse, J. D., Wennberg, P. O., Flagan, R. C., and Seinfeld, J. H.: Secondary organic aerosol (SOA) formation from reaction of isoprene with nitrate radicals $\left(\mathrm{NO}_{3}\right)$, Atmos. Chem. Phys., 8, 4117-4140, doi:10.5194/acp-84117-2008, 2008.

Odum, J. R., Hoffmann, T., Bowman, F., Collins, D., Flagan, R. C., and Seinfeld, J. H.: Gas/particle partitioning and secondary organic aerosol yields, Environ. Sci. Technol., 30, 2580-2585, 1996.

Pandis, S. N., Paulson, S. E., Seinfeld, J. H., and Flagan, R. C.: Aerosol formation in the photooxidation of isoprene and $\beta$ pinene, Atmos. Environ., 25A, 997-1008, 1991. 
Paulot, F., Crounse, J. D., Kjaergaard, H. G., Kürten, A., St. Clair, J. M., Seinfeld, J. H., and Wennberg, P. O.: Unexpected epoxide formation in the gas-phase photooxidation of isoprene, Science, 325, 730-733, 2009.

Qi, L., Nakao, S., Tang, P., and Cocker III, D. R.: Temperature effect on physical and chemical properties of secondary organic aerosol from $m$-xylene photooxidation, Atmos. Chem. Phys., 10, 3847-3854, doi:10.5194/acp-10-3847-2010, 2010.

Rollins, A. W., Kiendler-Scharr, A., Fry, J. L., Brauers, T., Brown, S. S., Dorn, H.-P., Dubé, W. P., Fuchs, H., Mensah, A., Mentel, T. F., Rohrer, F., Tillmann, R., Wegener, R., Wooldridge, P. J., and Cohen, R. C.: Isoprene oxidation by nitrate radical: alkyl nitrate and secondary organic aerosol yields, Atmos. Chem. Phys., 9, 6685-6703, doi:10.5194/acp-9-6685-2009, 2009.

Sato, K.: Detection of nitrooxypolyols in secondary organic aerosol formed from the photooxidation of conjugated dienes under high- $\mathrm{NO}_{\mathrm{x}}$ conditions, Atmos. Environ., 42, 6851-6861, 2008.

Sato, K., Klotz, B, Hatakeyama, S., Imamura, T., Washizu, Y., Matsumi, Y., and Washida, N.: Secondary organic aerosol formation during the photo-oxidation of toluene: dependence on initial hydrocarbon concentration, Bull. Chem. Soc. Jpn., 77, 667-671, 2004.

Sato, K., Takami, A., Isozaki, T., Hikida, T., Shimono, A., and Imamura, T.: Mass spectrometric study of secondary organic aerosol formed from the photo-oxidation of aromatic hydrocarbons, Atmos. Environ., 44, 1080-1087, 2010.

Shi, J. P. and Harrison, R. M.: Rapid $\mathrm{NO}_{2}$ formation in diluted petrol-fuelled engine exhaust - A source of $\mathrm{NO}_{2}$ in winter smog episodes, Atmos. Environ., 31, 3857-3866, 1997.

Smith, D., Cheng, P., and Spanel, P.: Analysis of petrol and diesel vapour and vehicle engine exhaust gases using selected ion flow tube mass spectrometry, Rapid Commun. Mass Sp., 16, 11241134, 2002.

Surratt, J. D., Murphy, S. M., Kroll, J. H., Ng, N. L., Hildebrandt, L., Sorooshian, A., Szmigielski, R., Vermeylen, R., Maenhaut, W., Claeys, M., Flagan, R. C., and Seinfeld, J. H.: Chemical composition of secondary organic aerosol formed from the photooxidation of isoprene, J. Phys. Chem. A, 110, 9665-9690, 2006.

Surratt, J. D., Lewandowski, M., Offenberg, J. H., Jaoui, M., Kleindienst, T. E., Edney, E. O., and Seinfeld, J. H.: Effect of acidity on secondary organic aerosol formation from isoprene, Environ. Sci. Technol., 41, 5363-5369, 2007.
Surratt, J. D., Gómez-González, Y., Chan, A. W. H., Vermeylen, R., Shahgholi, M., Kleindienst, T. E., Edney, E. O., Offenberg, J. H., Lewandowski, M., Jaoui, M., Maenhaut, W., Claeys, M., Flagan, R. C., and Seinfeld, J. H.: Organosulfate formation in biogenic secondary organic aerosol, J. Phys. Chem. A., 112, 8345-8378, 2008.

Surratt, J. D., Chan, A. W. H., Eddingsaas, N. C., Chan, M. N., Loza, C. L., Kwan, A. J., Hersey, S. P., Flagan, R. C., Wennberg, P. O., and Seinfeld, J. H.: Reactive intermediates revealed in secondary organic aerosol formation from isoprene, P. Natl. Acad. Sci. USA, 1007, 6640-6645, 2010.

Szmigielski, R., Surratt, J. D., Vermeylen, R., Szmigielska, K., Kroll, J. H., Ng, N. L., Murphy, S. M., Sorooshian, A., Seinfeld, J. H., and Claeys, M.: Characterization of 2-methylglyceric acid oligomers in secondary organic aerosol formed from the photooxidation of isoprene using trimethylsilylation and gas chromatography/ion trap mass spectrometry, J. Mass. Spectrom., 42, 101-116, 2007.

Szmigielski, R., Dommen, J., Metzger, A., Maenhaut, W., Baltensperger, U., and Claeys, M.: The acid effect in the formation of 2-methyltetrols from the photooxidation of isoprene in the presence of $\mathrm{NO}_{\mathrm{x}}$, Atmos. Res., 98, 183-189, 2010.

Takekawa, H., Minoura, H., and Yamazaki, S.: Temperature dependence of secondary organic aerosol formation by photo-oxidation of hydrocarbons, Atmos. Environ., 37, 3413-3424, 2003.

ToF-AMS Software Downloads: http://cires.colorado.edu/ jimenez-group/ToFAMSResources/ (last access: 12 January 2010), 2009.

Treacy, J., El Hag, M., O’Farrell, D., and Sidebottom, H.: Reactions of ozone with unsaturated organic compounds, Ber. Bunsenges. Phys. Chem., 96, 422-427, 1992.

Wang, W., Kourtchev, I., Graham, B., Cafmeyer, J., Maenhaut, W., and Claeys, M.: Characterization of oxygenated derivatives of isoprene related to 2-methyltetrols in Amazonian aerosols using trimethylsilylation and gas chromatography/ion trap mass spectrometry, Rapid Commun. Mass Spectrom., 19, 1343-1351, 2005.

Xia, X. and Hopke, P. K.: Seasonal variation of 2-methyltetrols in ambient air samples, Environ. Sci. Technol., 40, 6934-6937, 2006.

Yokouchi, Y.: Seasonal and diurnal-variation of isoprene and its reaction-products in a semirural area, Atmos. Environ., 28, 2651-2658, 1994. 